\title{
Fate of cobalt and nickel in mackinawite during diagenetic pyrite formation
}

\author{
ElizabeTh D. SWANNER ${ }^{1,2, *, \dagger, \text { SAMUEl M. WEBB }}{ }^{3}$, AND ANDREAS KAPPLER ${ }^{2}$ \\ ${ }^{1}$ Department of Geological \& Atmospheric Sciences, Iowa State University, 2237 Osborn Drive, 253 Science Hall, \\ Ames, Iowa 50011-1027, U.S.A. Orcid 0000-0001-9507-0893 \\ ${ }^{2}$ Center for Applied Geoscience, University of Tübingen, Hölderlinstrasse 12, 72076 Tübingen, Germany \\ ${ }^{3}$ Stanford Synchrotron Radiation Lightsource, SLAC National Accelerator Laboratory, 2575 Sand Hill Road, MS 69, \\ Menlo Park, California 94025, U.S.A.
}

\begin{abstract}
As iron sulfide mineral phases are important sedimentary sinks for naturally occurring or contaminant metals, it is important to know the fate of metals during the diagenetic transformation of primary sulfide minerals into more stable phases, such as pyrite $\left(\mathrm{FeS}_{2}\right)$. Furthermore, the trace metal content of pyrite has been proposed as a marine paleoredox proxy. Given the diverse low-temperature diagenetic formation pathways for pyrite, this use of pyrite requires validation. We, therefore, studied nickel (Ni) and cobalt $(\mathrm{Co})$ incorporation into freshly precipitated mackinawite $\left(\mathrm{FeS}_{\mathrm{m}}\right)$, and after experimental diagenesis to pyrite $\left(\mathrm{FeS}_{2}\right)$ using $\mathrm{S}^{0}$ as an oxidant at $65^{\circ} \mathrm{C}$. Metal incorporation was quantified on bulk digests using ICP-OES or ICP-AES. Bulk mineralogy was characterized with micro-X-ray diffraction (micro-XRD), documenting the transformation of mackinawite to pyrite. Epoxy grain mounts were made anoxically of mackinawite and pyrite grains. We used synchrotron-based micro-X-ray fluorescence $(\mu \mathrm{XRF})$ to map the distribution of $\mathrm{Co}$ and $\mathrm{Ni}$, as well as to collect multiple energy maps throughout the sulfur (S) $K$-edge. Iron ( $\mathrm{Fe}$ ) and $\mathrm{S} K$-edge micro-X-ray absorption near edge spectroscopy ( $\mu \mathrm{XANES}$ ) was used to identify the oxidation state and mineralogy within the experimentally synthesized and diagenetically transformed minerals, and map end-member solid phases within the grain mounts using the multiple energy maps. Metal-free $\mathrm{FeS}_{\mathrm{m}}$ transformed to pyrite, with residual $\mathrm{FeS}_{\mathrm{m}}$ detectable. $\mathrm{Co}$ - and Ni-containing $\mathrm{FeS}_{\mathrm{m}}$ also transformed to pyrite, but with multiple techniques detecting $\mathrm{FeS}_{\mathrm{m}}$ as well as $\mathrm{S}^{0}$, implying less complete transformation to pyrite as compared to metal-free $\mathrm{FeS}_{\mathrm{m}}$. These results indicate that $\mathrm{Co}$ and $\mathrm{Ni}$ may inhibit transformation for $\mathrm{FeS}_{\mathrm{m}}$ to pyrite, or slow it down. Cobalt concentrations in the solid diminished by $30 \%$ during pyrite transformation, indicating that pyrite Co may be a conservative tracer of seawater or porewater Co concentrations. Nickel concentrations increased several-fold after pyrite formation, suggesting that pyrite may have scavenged $\mathrm{Ni}$ from the dissolution of primary $\mathrm{FeS}_{\mathrm{m}}$ grains. Nickel in pyrites thus may not be a reliable proxy for seawater or porewater metal concentrations.
\end{abstract}

Keywords: Mackinawite, pyrite, diagenesis, cobalt, nickel, X-ray absorption spectroscopy, X-ray fluorescence; Understanding Paleo-Ocean Proxies: Insights from in situ analyses

\section{INTRODUCTION}

Pyrite $\left(\mathrm{FeS}_{2}\right)$ is the most abundant iron sulfide mineral on the surface of the Earth (Rickard and Luther 2007) and has formed in marine sediments (e.g., "diagenetic" pyrite) for at least 3.5 billion years (Gy) (Shen et al. 2001). The presence of pyrite, as well as its isotopic and elemental composition, has been applied to determining the redox conditions of the site of deposition, as well as the atmosphere and oceans. For instance, the presence of detrital pyrite in sediments $>2$ Gy old was one of the early indications of an anoxic Archean atmosphere (Holland 1984). Because of the enhanced mobilization of sulfate to the oceans from weathering of continental pyrite as oxygen appeared in the atmosphere, the presence of marine pyrite, formed either authigenically or diagenetically, tracks the timing of oxidation of the

\footnotetext{
* E-mail: eswanner@iastate.edu

$\uparrow$ Special collection papers can be found online at http://www.minsocam.org/MSA/ AmMin/special-collections.html.
}

Earth and atmosphere. Pyrite Fe and $\mathrm{S}$ isotopes are exploited to track the magnitude of pyrite burial through time (Rouxel et al. 2005; Tostevin et al. 2014), the amount of sulfate in the oceans (Canfield and Farquhar 2009), as well as atmospheric and ocean oxygenation (Mojzsis et al. 2003; Rouxel et al. 2005; Konhauser et al. 2011; Fakhraee et al. 2018).

Increasingly, though, scientists are also looking into the trace metal inventory of sedimentary pyrite as a reflection of the trace metal contents and redox conditions of the overlying water column. While investigations of trace metals in bulk clastic sediments, such as shales, are useful for this purpose, these studies tend to better highlight the utility of elements that undergo extreme authigenic enrichments in sediments under certain redox conditions (Algeo and Maynard 2004; Algeo and Rowe 2012), rather than those that are specifically incorporated by pyrite. The trace metals that become incorporated into pyrite by coprecipitation can reflect either the abundance of these elements in seawater (Huerta-Diaz and Morse 1992), and the metals can be 
sequentially extracted from existing sulfide phases (Huerta-Diaz and Morse 1990). Such targeted extractions can be extremely useful for modern sediments where multiple sulfide minerals may be present (e.g., Scholz and Neumann 2007; Olson et al. 2017).

As sediments lithify, there is a potential for resetting of the trace metal contents by diagenesis, fluid alteration, or metamorphism. Extraction of pyrites and associated trace elements in clastic rocks is subject to limitations based on extraction efficiency or extraction specificity (Harrison et al. 1973). In situ analysis of trace metals in pyrite by methods such as laser ablation ICP-MS (e.g., Large et al. 2014; Gregory et al. 2015) or electron microprobe microanalysis (EPMA) coupled to wavelength-dispersive spectroscopy (WDS) have the utility of unambiguously assigning metal enrichments to pyrite vs. other phases (e.g., organics, detrital minerals, or authigenic precipitates such as $\mathrm{Fe}-$ and/or Mn-oxides) (Chappaz et al. 2014). Laser ablation ICP-MS paths and quantitative elemental maps made by EPMA of individual pyrite grains, nodules, or framboids can also help to distinguish primary enrichments of trace metals from later overgrowths (Large et al. 2009; Swanner et al. 2013). Such findings are valuable to understanding pathways for economically significant trace metal enrichments (Tardani et al. 2017).

The availability of bioessential metals [e.g., Ni, $\mathrm{Co}, \mathrm{Cu}, \mathrm{Mo}$, $\mathrm{Zn}, \mathrm{Se}$, etc.] in the Precambrian oceans is widely agreed to have controlled the origination and activity of microbial functional groups throughout Earth's history, due to the use of metals as active centers in enzymes or in organic co-factors (Anbar and Knoll 2002). While there has been an effort to infer changes in the abundance of metals in the environment through the genomic and metallomic inventory of modern organisms (Dupont et al. 2006, 2010), direct sedimentary records of metal availability are necessary for constraining the availability of metals (Robbins et al. 2016). As with modern sediments discussed above, the bulk rock inventory or trace metals in shales deposited throughout Earth's history is useful for informing general metal availability in the early oceans (e.g., Scott et al. 2008, 2012). Mineral specific metal analyses of chemical sediments, such as iron formations (Konhauser et al. 2009; Partin et al. 2013; Robbins et al. 2013; Swanner et al. 2014; Chi Fru et al. 2016), and in situ metal quantification directly from diagenetic pyrite (Large et al. 2014; Swanner et al. 2014; Long et al. 2016) can complement bulk analyses, and even provide direct estimates of seawater concentrations of some elements (Konhauser et al. 2009). Multiple, temporally resolved metal records from several sedimentary reservoirs highlight the co-evolution of life and its role in influencing ocean and atmospheric redox chemistry, in addition to its reaction to it (Robbins et al. 2016).

$\mathrm{Co}$ and $\mathrm{Ni}$ are a bioessential elements that are incorporated into iron sulfide precipitates (e.g., mackinawite), unlike metals that precipitate directly with sulfide (e.g., HgS) (Morse and Arakaki 1993), a result of the kinetics of exchange between water ligands for sulfide $\left(\mathrm{S}^{2-}\right)$ (Morse and Luther 1999). This means that the incorporation of $\mathrm{Co}$ and $\mathrm{Ni}$ into mackinawite is predictable with a partition coefficient (Morse and Arakaki 1993), an observation validated by the near-quantitative incorporation of these elements from porewaters into sulfide minerals, including pyrite (Scholz and Neumann 2007; Olson et al. 2017). Changes in the marine Co reservoir through time determined from pyrite, bulk black shale, and iron formation Co contents are consistent, and indicate that pyrite Co contents may reflect concentrations in the water column (Swanner et al. 2014). Nickel is expected to behave similarly in the pyrite system (Morse and Arakaki 1993). Using the marine sedimentary record as an indicator of marine metal reservoirs presumes that diagenesis does not alter the original metal contents of these sediments. However, diagenetic metal mobilization is a possibility for iron (oxy)hydroxides (Frierdich et al. 2011), and loss, gain or redistribution of Co or Ni could occur as primary iron sulfides (e.g., mackinawite, greigite, or the aqueous $\mathrm{FeS}$ cluster, $\mathrm{FeS}_{\mathrm{aq}}$ ) are transformed to pyrite during low-temperature diagenesis (i.e., $<80^{\circ} \mathrm{C}$ ) or later fluid alteration.

The formation pathways of pyrite are debated, but it is generally understood that pyrite forms from an aqueous or precipitated $\mathrm{FeS}$ phase, such as mackinawite, greigite, or an aqueous or nanoparticulate $\mathrm{FeS}$ cluster (e.g., $\mathrm{FeS}_{\mathrm{aq}}$ ) (Luther and Rickard 2005). At low temperatures (i.e., below $80^{\circ} \mathrm{C}$ ), hydrogen sulfide $\left(\mathrm{H}_{2} \mathrm{~S}\right)$ is the product of microbial sulfate reduction at circumneutral pH (Jørgensen 1982), which can then precipitate with dissolved $\mathrm{Fe}^{2+}$ to form an $\mathrm{FeS}$ phase. The presence of $\mathrm{S}$ in the $\mathrm{S}^{1-}$ oxidation state in pyrite indicates that $\mathrm{S}$ in any primary FeS precipitate must be oxidized from $\mathrm{S}^{2-}$ and Fe removed (or $\mathrm{S}$ added) to form the mineral pyrite (Goldhaber and Kaplan 1974). This has been accomplished experimentally through oxidation of FeS solids (mackinawite or greigite) with $\mathrm{S}^{0}$ (Berner 1970; Sweeney 1972; Schoonen and Barnes 1991b), polysulfides (i.e., chains of $\mathrm{S}^{0}$ and $\mathrm{S}^{-1}$ ) (Rickard 1969; Hunger and Benning 2007), or $\mathrm{H}_{2} \mathrm{~S}$ (Rickard 1997; Rickard and Luther 1997; Butler and Rickard 2000). Although the degree to which solid FeS minerals such as mackinawite actually exists in sediments has been questioned due to bias with the traditional acid-volatile sulfide (AVS) extraction (Rickard and Morse 2005), numerous studies have directly detected mackinawite (Burton et al. 2009; Morgan et al. 2012a; Kraal et al. 2013) and greigite (Keene et al. 2011) in the environment, justifying the use of these solids as precursor materials. Another possible formation route is direct pyrite formation through reductive dissolution or surface reactions of $\mathrm{Fe}(\mathrm{III})$ (oxyhydr)oxide minerals with $\mathrm{H}_{2} \mathrm{~S}$ or polysulfides (Hellige et al. 2012; Peiffer et al. 2015; Wan et al. 2017). While specific mechanistic details vary, reaction of dissolved species and dissolution or recrystallization of an initial solid phase, such as mackinawite or greigite, and subsequent nucleation of pyrite are generally invoked (Wang and Morse 1996; Rickard and Luther 1997). Such reactions could mobilize trace metals co-precipitated or adsorbed with precursor phases.

In this study, two different pathways were used to convert freshly precipitated mackinawite $\left(\mathrm{FeS}_{\mathrm{m}}\right)$ containing $\mathrm{Co}$ and/or $\mathrm{Ni}$ into pyrite. The amount of metal in the $\mathrm{FeS}_{\mathrm{m}}$ and pyrite were quantified by bulk and microscale techniques to determine whether these metals are retained through diagenesis. Bulk and microscale techniques for both mineralogy and trace element quantification were coupled to give insights on the influence of these metals in promoting or inhibiting diagenetic pyrite formation.

\section{METHODS}

\section{Mineral synthesis}

Mackinawite $\left(\mathrm{FeS}_{\mathrm{m}}\right)$ was synthesized from solutions of $0.6 \mathrm{M}$ ferrous ammonium sulfate $\left[\mathrm{Fe}\left(\mathrm{NH}_{4}\right)_{2}\left(\mathrm{SO}_{4}\right)_{2}\right]$ and $0.6 \mathrm{M}$ sodium sulfide $\left(\mathrm{Na}_{2} \mathrm{~S}\right)$ (Rickard 1997). 
Both solutions were made with ultrapure water (conductivity $0.052 \mu \mathrm{S}$ ) that had been boiled and cooled under an $\mathrm{N}_{2}$ stream to make it anoxic. Sodium sulfide crystals were washed for $30 \mathrm{~s}$ with anoxic water to remove any oxidized S-species from the surface, then water was removed with a Pasteur pipette. Washed crystals were dried under an $\mathrm{N}_{2}$ stream and stored in a $\mathrm{N}_{2}$ atmosphere within a glass bottle with a butyl rubber stopper. Washed sodium sulfide crystals were weighed in an anoxic glovebox $\left(100 \% \mathrm{~N}_{2}\right)$. The ferrous ammonium sulfate and sodium sulfide solutions were made in glass serum bottles and sealed with butyl rubber stoppers with an $\mathrm{N}_{2}$ headspace. To synthesize $\mathrm{FeS}_{\mathrm{m}}$, equal volumes of each solution were added via $\mathrm{N}_{2}$-purged syringes to a previously $\mathrm{N}_{2}$-purged and stoppered serum bottle under a slight vacuum $(0.5 \mathrm{mbar})$. $\mathrm{FeS}_{\mathrm{m}}$ precipitated immediately. For the synthesis of $\mathrm{FeS}_{\mathrm{m}}$ that contained either $\mathrm{Ni}$ or $\mathrm{Co}, 4.7 \mathrm{mg} \mathrm{NiCl}_{2} \cdot 6 \mathrm{H}_{2} \mathrm{O}$ or $190 \mathrm{mg} \mathrm{CoCl} \mathrm{Cl}_{2} \cdot 6 \mathrm{H}_{2} \mathrm{O}$ powders were weighed into serum bottles and stoppered, then flushed with $\mathrm{N}_{2}$. This was accomplished by introducing $\mathrm{N}_{2}$ through a long needle, which bubbled the solution, and letting the overpressure escape through a second, shorter needle. An appropriate volume of the ferrous ammonium sulfate solution was added to achieve concentrations of $500 \mu \mathrm{M} \mathrm{Ni}$ or $2000 \mu \mathrm{M}$ Co when mixed with the sodium sulfide solution. These solutions were then mixed with sodium sulfide as described above.

Pyrite synthesis was attempted by two different methods. The first, oxidation of $\mathrm{FeS}_{\mathrm{m}}$ with $\mathrm{H}_{2} \mathrm{~S}$ (Rickard 1997) (hereafter " $\mathrm{H}_{2} \mathrm{~S}$ oxidation"), was attempted to circumvent introduction of other solid S species (e.g., elemental sulfur, $\mathrm{S}^{0}$ ) that would be detected with later microanalysis. The reaction 13323-4 of Rickard (1997) was chosen (400 mg ferrous ammonium sulfate, $80{ }^{\circ} \mathrm{C}, \mathrm{pH} 6,-250 \mathrm{mV}, 4 \mathrm{mM}$ $\left.\mathrm{H}_{2} \mathrm{~S}\right)$, as partial pyrite synthesis was reported from that reaction $(80 \%$ pyrite and $20 \%$ mackinawite). Partial synthesis was desirable so that the partitioning of Co and Ni between the primary and secondary mineral could be evaluated. The anoxic solution of Ti(III) citrate and the phthalate buffer were made as described (Rickard 1997). The $\mathrm{Na}_{2} \mathrm{~S}$ solution was made as described for mackinawite synthesis but then adjusted to $\mathrm{pH} 6$ with anoxic $1 \mathrm{~N} \mathrm{HCl}$. Dry $\mathrm{FeS}_{\mathrm{m}}$ was weighed into a glass headspace vial with a small stir bar and closed with a stopper inside the glovebox. The buffer solution, $\mathrm{Ti}(\mathrm{III})$ citrate solution, and the $\mathrm{Na}_{2} \mathrm{~S}$ solution were introduced via syringes that had been flushed with $\mathrm{N}_{2}$. The mixture was incubated in a sand bath at $80^{\circ} \mathrm{C}$ on a temperature regulated hot plate, stirring, for either 4 or 20 days. At the end of the reaction, the headspace was flushed with $\mathrm{N}_{2}$.

The second pyrite synthesis method reacted $\mathrm{FeS}_{\mathrm{m}}$ with orthorhombic sulfur $\left(\mathrm{S}_{8}\right.$, with sulfur in the $\mathrm{S}^{0}$ oxidation state) (Schoonen and Barnes 1991b), hereafter "sulfur oxidation." $\mathrm{FeS}_{\mathrm{m}}$ was synthesized as described above. Dried $\mathrm{FeS}_{\mathrm{m}}$ (see below) was resuspended with $\mathrm{pH} 6$ anoxic phthalate buffer in a stoppered serum vial. Orthorhombic sulfur was weighed and placed into a stoppered headspace vial, then the headspace was exchanged with $\mathrm{N}_{2}$. Inside the glovebox, the orthorhombic sulfur and a small stir bar were added to the $\mathrm{FeS}_{\mathrm{m}}$-buffer solution and crimped with butyl rubber stoppers. The vials were placed in a sand bath at $65^{\circ} \mathrm{C}$ on a temperature regulated hot plate, stirring, for 2 weeks. At the end of the reaction, the mineral suspension was centrifuged at $4000 \mathrm{rpm}$, the liquid removed with a 2 -inch needle, and carbon disulfide $\left(\mathrm{CS}_{2}\right)$ was introduced from a stock under $\mathrm{N}_{2}$ atmosphere to solubilize the unreacted orthorhombic sulfur. The suspension was centrifuged once again and $\mathrm{CS}_{2}$ removed prior to washing of the suspension with water (see below).

After synthesis, minerals in solution were spun at $4000 \mathrm{rpm}$ for $10 \mathrm{~min}$ while still sealed in glass serum bottles. The liquid was removed with a 2 -inch needle while $\mathrm{N}_{2}$ was being injected into the headspace using a second needle to maintain atmospheric pressure. Anoxic ultrapure water was added to the mineral suspension, and centrifugation repeated until the suspension had been washed twice. Then, vials were moved into the glovebox where the stoppers were removed. The serum bottles were covered with a paper tissue held in place by rubber bands. They were then placed in the vacuum chamber of the glovebox under a vacuum of -0.8 mbar until dried. Dried samples were stored in stoppered, $\mathrm{N}_{2}$-filled glass bottles at room temperature until further use.

All glassware used in the above protocols was acid washed for at least $24 \mathrm{~h}$ in $1 \mathrm{~N} \mathrm{HCl}$. This was followed by a $24 \mathrm{~h}$ soak in ultrapure water, followed by three rinses in fresh ultrapure water.

\section{Embedding and polishing}

Dried samples of synthetic mineral grains were sprinkled into plastic 1-inch diameter rounds either on the bench or inside a glovebox $\left(90 \% \mathrm{~N}_{2} / 10 \% \mathrm{H}_{2}\right)$. Samples were then immediately placed under vacuum within a Polyvac vacuum impregnator (Presi $\mathrm{GmbH}$ ) at $80 \mathrm{kPa}$ for $15 \mathrm{~min}$. Then, Araldite epoxy $2020 \mathrm{~A} / \mathrm{B}$ was slowly added (100:35 vol) until the sample was covered. Embedding proceeded at $80 \mathrm{kPa}$ for $90 \mathrm{~min}$. Samples were left to set for $24 \mathrm{~h}$ before removing from the impregnator.

Embedded samples were first ground with abrasive papers: $1200(15 \mu \mathrm{m})$, then $2500(8 \mu \mathrm{m})$ using a PRESI Mecatech 334. Polishing utilized a PRESI diamond stick LD 33 ( $3 \mu \mathrm{m})$ and Presi RAM polishing cloth, followed by a final polish with $0.05 \mu \mathrm{m}$ deagglomerated $\gamma$ alumina on a Buehler Chemomet I cloth (BUEHLER Micropolisch II $0.05 \mu \mathrm{m}$ ). Sample mounts were stored and transported in a nitrogen atmosphere. Just prior to synchrotron-based microanalysis, samples were polished with a $1 \mu \mathrm{m}$ cloth to remove oxidized coatings.

\section{Bulk analysis}

Particle size of synthesized samples was analyzed with a Mastersizer 2000 (Malvern Instruments $\mathrm{GmbH}$ ). The surface area of solids was analyzed using a Micromeritics ASAP 2000 BET analyzer. Dried samples were loaded onto a holder and kept anoxic $\left(100 \% \mathrm{~N}_{2}\right)$ until directly before analysis by $\mu$-X-ray diffraction (XRD) on a Bruker D8 Discover instrument (Bruker, Germany) equipped with a $\mathrm{Co} K \alpha \mathrm{X}$-ray tube $(\mathrm{k}=0.17902 \mathrm{~nm}, 30 \mathrm{kV}, 30 \mathrm{~mA})$ and GADDS area detector (Berthold et al. 2009). Mineral phases were identified using the International Center for Diffraction Data (ICDD) database.

Bulk trace element measurements were carried out by ICP-OES (Perkin Elmer Optima 5300 or Horiba Ultima 2) or an ICP-AES at University of Tübingen. Mineral samples (5-30 mg) were digested with aqua regia: $0.5 \mathrm{~mL}$ concentrated trace metal grade (TMG) $\mathrm{HNO}_{3}(65 \%)$ and $1.5 \mathrm{~mL}$ concentrated $\mathrm{HCl}$ at $60{ }^{\circ} \mathrm{C}$. Residues were resuspended in $8 \mathrm{NTMG} \mathrm{HNO}_{3}$, and diluted 10-fold in $2 \% \mathrm{TMG} \mathrm{HNO}_{3}$. Elemental sulfur that did not dissolve was filtered through a $0.2 \mu \mathrm{m}$ Whatman filter. Aqueous samples were preserved with and further diluted in $2 \% \mathrm{TMG} \mathrm{HNO}_{3}$.

\section{Microscale analysis and spectroscopy}

Elemental mapping by micro-X-ray fluorescence ( $\mu \mathrm{XRF}$ ) and $\mathrm{S}$ and $\mathrm{Fe} K$-edge $\mathrm{X}$-ray absorption near-edge structure (XANES) spectroscopy was performed at beamlines (BL) 14-3 and 2-3, respectively at Stanford Synchrotron Radiation Lightsource (SSRL). Sulfur distribution was mapped in approximately $1 \times 1 \mathrm{~mm}$ areas at $\sim 2500 \mathrm{eV}$ on BL14-3, which has an energy range of 2100 to $5000 \mathrm{eV}$. The incident energy was selected using a $\operatorname{Si}(111) \phi=90$ double crystal monochromator and the fluorescence signal was collected with a Si-drift diode Vortex detector (Hitachi) coupled to an Xspress3 pulse processing system (Quantum Detectors). The energy was calibrated to the thiosulfate pre-edge peak set to $2472.02 \mathrm{eV}$ or a sulfate peak from $\mathrm{CaSO}_{4}$ set to $2483 \mathrm{eV}$. The spot size was $5 \times 5 \mu \mathrm{m}$, unless otherwise noted, and dwell times were between 50 to $200 \mu$ s. For a subset of samples, S maps were collected at multiple energies (ME) around the $\mathrm{S} K$-edge that corresponded to characteristic absorption features for monosulfides, pyrite, elemental sulfur, sulfite/metal monosulfides, sulfate, and total sulfur, in order of increasing energy. In 2013 these energies were 2470, 2471.5, 2472.5, 2476.5, 2483, and $2490 \mathrm{eV}$. In 2014 they were $2469.7,2471.2,2472.2,2476.2,2482.7$, and $2499 \mathrm{eV}$. In 2015 and 2016 these energies were 2470.7, 2471.1, 2472.6, 2478.5, 2482.5, and $2499 \mathrm{eV}$. These maps were then deadtime corrected, and subjected to a principle component analysis (PCA) in the Microanalysis Toolkit (http://smak.sams-xrays.com) (Webb 2011). Compositionally diverse spots based on the absorption at different energies above the S $K$-edge were revealed by PCA, and these spots were chosen for S $K$-edge spectroscopy. Fluorescence spectra were collected from 2460 to $2500 \mathrm{eV}$. Spectra were deadtime corrected and normalized using the SIXPACK software package (Webb 2005). Within SIXPACK, the collected spectra from each sample ( 3 to 23 spectra per sample) were subjected to PCA to reveal the number of unique spectra. These end-members (EM), representing the compositional heterogeneity of all $\mu$ XANES from an individual sample, were then fitted with spectra of reference sulfur compounds available from the ESRF (https://www.esrf.eu/home/ UsersAndScience/Experiments/XNP/ID21/php.html), and additional samples from mineral collections and laboratory synthesis that were analyzed on BL 14-3 [these include mackinawite (FeS) and polysulfide]. Mackinawite was bulk dried powder from the $\mathrm{FeS}_{\mathrm{m}}$ synthesis described above, without added metals. The distribution of EM was then back-mapped using the characteristic fluorescence intensities at the specific energies in the MicroAnalysis Toolkit, similar to published methods (Mayhew et al. 2011; Farfan et al. 2018).

Iron, sulfur, and trace metals were mapped in approximately $0.5 \times 0.5 \mathrm{~mm}$ areas at $8500 \mathrm{eV}$ on BL2-3, which has an energy range of 4500 to $24000 \mathrm{eV}$. The incident energy was selected using a $\operatorname{Si}(111) \phi=0$ double crystal monochromator, and the fluorescence signal was collected with a Si-drift diode Vortex detector (Hitachi) coupled to an Xspress 3 pulse processing system (Quantum Detectors). The energy was calibrated using the first inflection of an $\mathrm{Fe}^{0}$ foil as a standard $(7112 \mathrm{eV})$. The spot size was either $2 \times 2$ or $5 \times 5 \mu \mathrm{m}$, and dwell times were between 50 to $200 \mu \mathrm{s}$. Spots with different element intensities were chosen for Fe $K$-edge XANES ( 3 to 10 spectra per sample). Data were processed as described above.

Reference spectra used for fitting Fe $K$-edge XANES have been previously published (O'Day et al. 2004). Additional reference spectra were for Fe XANES 
collected as bulk samples on BL 4-1 at SSRL. Powdered samples were analyzed in sandwiches of "Kapton" tape, or in "Teflon" (polytetrafluoroethylene) holder windows sealed with Kapton tape. Where necessary, powders were diluted with boron nitride to reduce self-absorption effects. The XANES spectra were collected in transmission mode as well as in fluorescence mode using a Lytle detector. The $\mathrm{E}_{0}$ of an $\mathrm{Fe}^{0}$ metal foil placed behind the first transmission detector was adjusted to $7112 \mathrm{eV}$ to energy calibrate the resulting spectra. Replicate spectra were then averaged and background subtracted in SIXPACK (Webb 2005).

Semi-quantitative analysis of elemental abundance was accomplished by calibrating to NIST-traceable standards of the elements of interest, which were deposited on mylar films measured at the same detector distance, incident energy, dwell time, spot size, and detector gain as the samples. A calibration file was assembled containing the information from the standard maps in the MicroAnalysis Toolkit, and applied to the sample. Because the samples were in thick mounts, the sample thickness was approximated as the absorption length for the mineral host, either $\mathrm{FeS}_{\mathrm{m}}$ or $\mathrm{FeS}_{2}$. Because individual grains may be thinner, especially on the margins than this absorption thickness, it is important to emphasize that this approach is only semi-quantitative. The amount of element per area was converted to concentrations as milligram metal per gram sample assuming one absorption length of either $\mathrm{FeS}_{\mathrm{m}}$ or pyrite as the sample depth. A mask was applied to the image to eliminate pixels that did not represent $\mathrm{Fe}$ - and S-containing particles, and the statistics were calculated on the selected pixels by the MicroAnalysis Toolkit.

\section{RESULTS}

\section{Characteristics of synthesized minerals}

The bulk mineralogy of synthetic samples was determined by XRD. Reference minerals were mackinawite, greigite, pyrite, pyrrhotite, and elemental sulfur. Synthesized $\mathrm{FeS}_{\mathrm{m}}$ matched diffraction patterns for mackinawite, with minor greigite and pyrrhotite (Fig. 1). No peaks attributable to the iron oxides hematite, goethite, magnetite, or ferrihydrite were present (data not shown). The XRD pattern for $\mathrm{FeS}_{\mathrm{m}}$ with no metals was very similar to that with added Co or Ni. Transformation of $\mathrm{FeS}_{\mathrm{m}}$ with or without $\mathrm{Co}$ or $\mathrm{Ni}$ to pyrite via $\mathrm{H}_{2} \mathrm{~S}$ oxidation (Rickard 1997) did not produce pyrite. However, peaks for mackinawite were sharpest in the $\mathrm{FeS}_{\mathrm{m}}$ sample with no metals that reacted the longest - 20 days - whereas $\mathrm{FeS}_{\mathrm{m}}$ with either Co or Ni (reacted 4 days) had lower intensity peaks, the weakest in the sample that contained Ni. Pyrite was synthesized from $\mathrm{FeS}_{\mathrm{m}}$ both with and without $\mathrm{Co}$ or $\mathrm{Ni}$ using the sulfur oxidation protocol. Residual elemental sulfur was also detected in Co- and Ni-containing samples. The pyrite peaks had similar intensity irrespective of metal additions.

During synthesis with $0.1 \mathrm{~L}$ each of $0.6 \mathrm{M}$ ferrous ammonium sulfate and $\mathrm{Na}_{2} \mathrm{~S}$ solutions, $5.27 \mathrm{~g}$ of $\mathrm{FeS}_{\mathrm{m}}$ is calculated to have formed. $\mathrm{FeS}_{\mathrm{m}}$ had a BET surface area of $25.96 \pm 0.29 \mathrm{~m}^{2} / \mathrm{g}$, within the range of values reported in the literature for similar methodologies. Other BET measurements on synthetic freezedried $\mathrm{FeS}_{\mathrm{m}}$ resulted in $36.5 \mathrm{~m}^{2} / \mathrm{g}$ (Rickard 1997), 16-21 m²/g (Benning et al. 2000), and $47 \mathrm{~m}^{2} / \mathrm{g}$ (Wolthers et al. 2003). Particle size ranged from 2 to $138 \mu \mathrm{m}$, with greater than $90 \%$ of particles being less than $10 \mu \mathrm{m}$. Pyrite synthesized by sulfur oxidation had a BET surface area of $13.84 \pm 0.21 \mathrm{~m}^{2} / \mathrm{g}$. The surface area of Co-containing pyrite synthesized by sulfur oxidation was $18.06 \pm 0.12 \mathrm{~m}^{2} / \mathrm{g}$.

The results of $\mathrm{S} K$-edge XRF and S XANES mapping of $\mathrm{FeS}_{\mathrm{m}}$ synthesized with Co or Ni are shown in Figure 2, with the composition and fitting results of identified EM spectra reported in Table $1 . \mathrm{FeS}_{\mathrm{m}}$ synthesized without metals was not mapped at ME through the $\mathrm{S} K$-edge, so a similar map is not available. However, grains synthesized without metals were composed of FeS and sulfate, based on analysis of the spot S XANES spectra
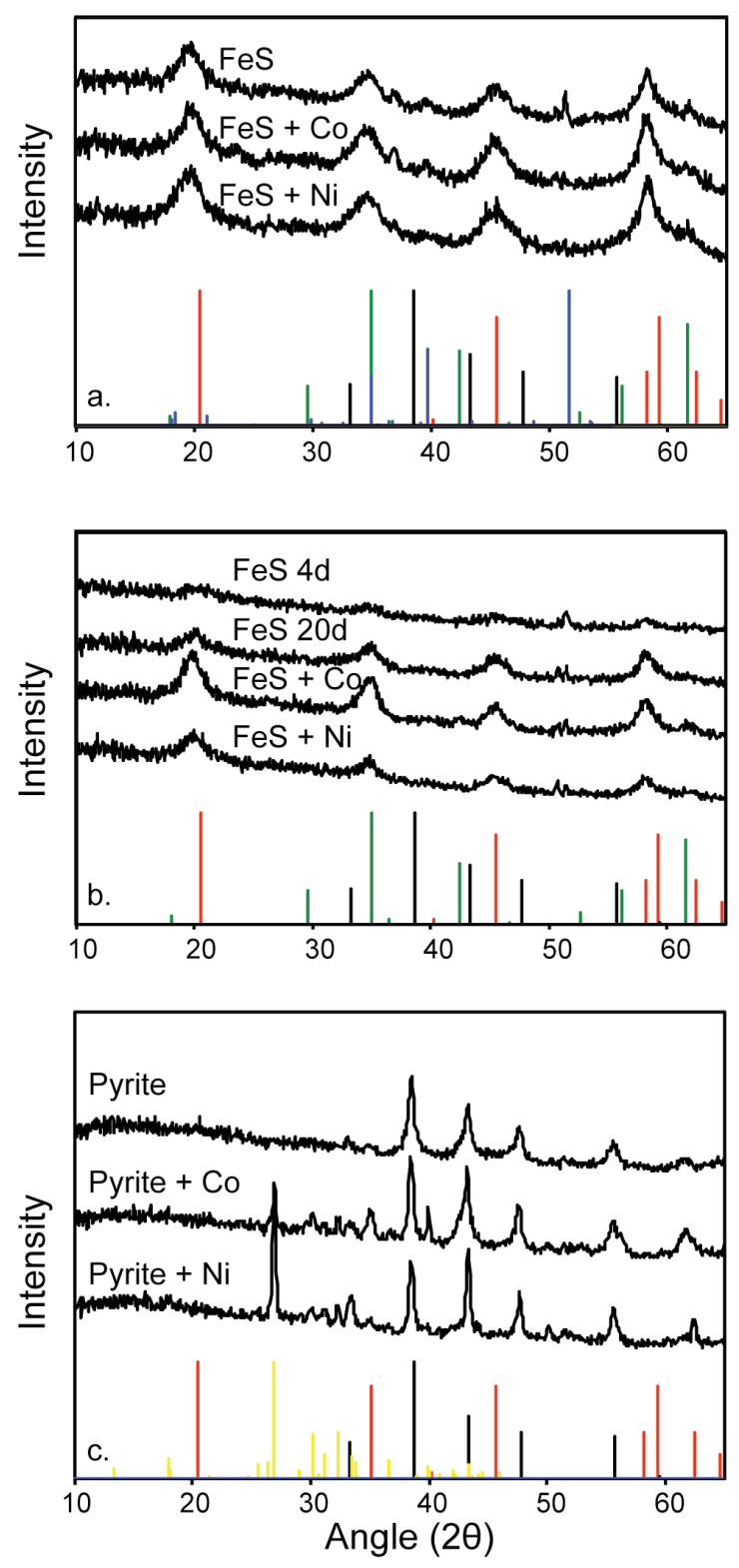

FIGURE 1. XRD of (a) FeS with and without Co and/or Ni, (b) FeS with and without $\mathrm{Co}$ and/or Ni after pyrite synthesis for 4 or 20 days using the $\mathrm{H}_{2} \mathrm{~S}$ oxidation protocol, and after pyrite synthesis with and without Co and/or Ni formed using the sulfur oxidation protocol. Reference reflections are shown for mackinawite (red), pyrite (black), elemental sulfur (yellow), greigite (green), and pyrrhotite (blue). Elemental sulfur was a residual phase following the sulfur oxidation protocol.

(Fig. 3; Table 1). The standard quenstedtite [a hydrated ferric sulfate, $\left.\mathrm{Fe}_{2}\left(\mathrm{SO}_{4}\right)_{3} \cdot 11 \mathrm{H}_{2} \mathrm{O}\right]$ was used as a proxy for the presence of an inorganic sulfate, as this fit all of the samples in the study requiring it fairly well. Substituting another sulfate mineral (e.g., anhydrite) did not change the fit significantly (e.g., more than $10 \%$ improvement on $\Sigma^{2}$ values; data not shown). It is important to note that inclusion of quenstedtite in the fit is not equivalent to detection of this mineral, as XANES is not a crystallographic technique. The use of quenstedtite in fits rather estimates the 

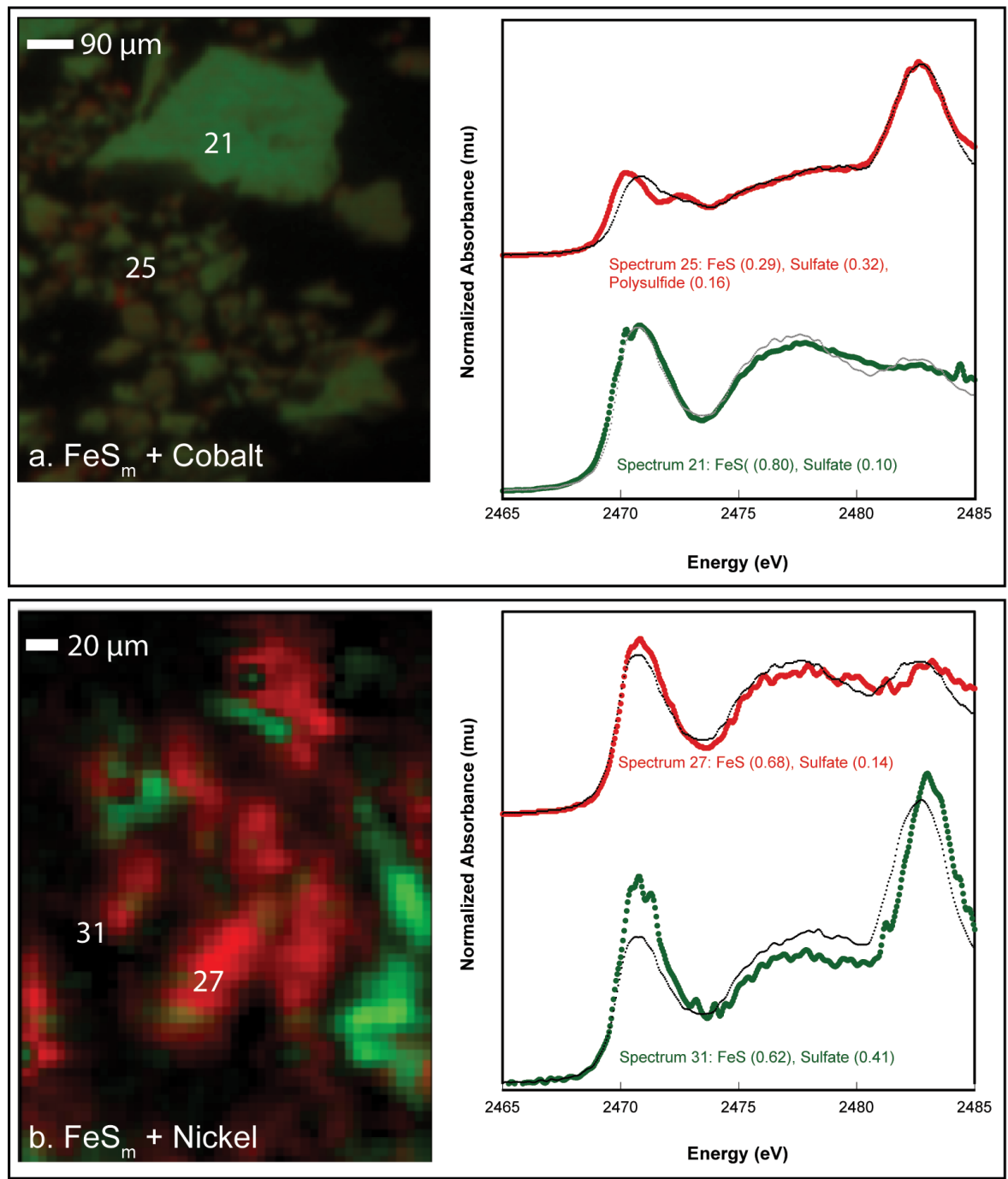

FIGURE 2. Phase distribution maps generated from multiple XRF maps within the $\mathrm{S} K$-edge and point XANES in FeS $\mathrm{m}_{\mathrm{m}}$ synthesized with Co or Ni. For each sample, the end-member XANES points labeled on the map (numbers) correspond to the spectra at right, and their distribution is shown in the same color as the corresponding spectra. Fits are dotted black lines. The fit compositions, as reported in Table 1, are also given. Note that $\mathrm{FeS}_{\mathrm{m}}$ synthesized without metals was not mapped at multiple XRF energies. (a) Results of $\mathrm{FeS}_{\mathrm{m}}$ synthesis with Co added. (b) Results FeS $\mathrm{m}$ synthesis with $\mathrm{Ni}$ added.

TABLE 1. Sulfur XANES fit data

\begin{tabular}{|c|c|c|c|c|c|c|c|c|c|}
\hline Sample & Number of spectra & End-member (EM) ID & $\mathrm{FeS}$ & Pyrite & Poly-sulfide & Sulfur & Sulfate ${ }^{\mathrm{a}}$ & Comp. sum & $\overline{\chi^{2}}$ \\
\hline FeS (embedded oxically; 2013) & 2 & 61 & 0.68 & & & & 0.37 & 1.05 & 6.71 \\
\hline \multirow[t]{2}{*}{ FeS (embedded anoxically; 2014) } & 10 & 80 & 0.68 & & & & 0.14 & 0.82 & 1.29 \\
\hline & & 88 & 0.47 & & 0.22 & & 0.21 & 0.90 & 1.64 \\
\hline \multirow[t]{2}{*}{ Pyrite (2015) } & 8 & 8 & 0.20 & 0.74 & & & 0.05 & 0.99 & 1.33 \\
\hline & & 10 & 0.06 & 0.78 & & & 0.11 & 0.95 & 0.51 \\
\hline \multirow[t]{2}{*}{$\mathrm{FeS}+\mathrm{Co}(2015)$} & 7 & 21 & 0.80 & & & & 0.10 & 0.9 & 1.78 \\
\hline & & 25 & 0.29 & & 0.16 & & 0.32 & 0.77 & 1.09 \\
\hline \multirow[t]{2}{*}{$\mathrm{FeS}+\mathrm{Co} \mathrm{H}_{2} \mathrm{~S}$ (2013) } & 8 & 23 & 0.88 & & & & & 0.88 & 3.13 \\
\hline & & 24 & 0.66 & & & & 0.11 & 0.77 & 3.73 \\
\hline \multirow[t]{2}{*}{ Pyrite + Co (2014) } & 12 & 4 & 0.12 & 0.63 & 0.22 & & & 0.96 & 1.02 \\
\hline & & 7 & & & 0.29 & 0.69 & & 0.98 & 3.17 \\
\hline \multirow[t]{2}{*}{$\mathrm{FeS}+\mathrm{Ni}(2013)$} & 23 & 27 & 0.68 & & & & 0.14 & 0.82 & 1.63 \\
\hline & & 31 & 0.62 & & & & 0.41 & 1.03 & 10.01 \\
\hline \multirow[t]{2}{*}{$\mathrm{FeS}+\mathrm{Ni} \mathrm{H}_{2} \mathrm{~S}(2013)$} & 10 & 2 & 0.82 & & & & 0.06 & 0.88 & 2.84 \\
\hline & & 4 & 0.83 & & & & 0.08 & 0.91 & 24.24 \\
\hline \multirow[t]{2}{*}{ Pyrite + Ni (2015) } & 9 & 29 & 0.15 & 0.73 & & & 0.05 & 0.93 & 0.69 \\
\hline & & 35 & & 0.79 & 0.25 & & & 1.04 & 1.83 \\
\hline
\end{tabular}

${ }^{a}$ The sulfate standard was quenstedtite. 
amount of an inorganic sulfate-bearing phase (Zeng et al. 2013). The $\mathrm{FeS}_{\mathrm{m}}$ synthesized in the presence of Co or Ni similarly were fit with FeS and sulfate (Fig. 2). Although ME mapping was not performed at the $\mathrm{Fe} K$-edge, Fe XANES from points on the $\mathrm{FeS}_{\mathrm{m}}$ with added Co sample map were fit by FeS and pyrrhotite (Table 2). In this case, the FeS spectra used was collected from a bulk powder of the $\mathrm{FeS}_{\mathrm{m}}$ synthesized without any metals. $\mathrm{FeS}_{\mathrm{m}}$
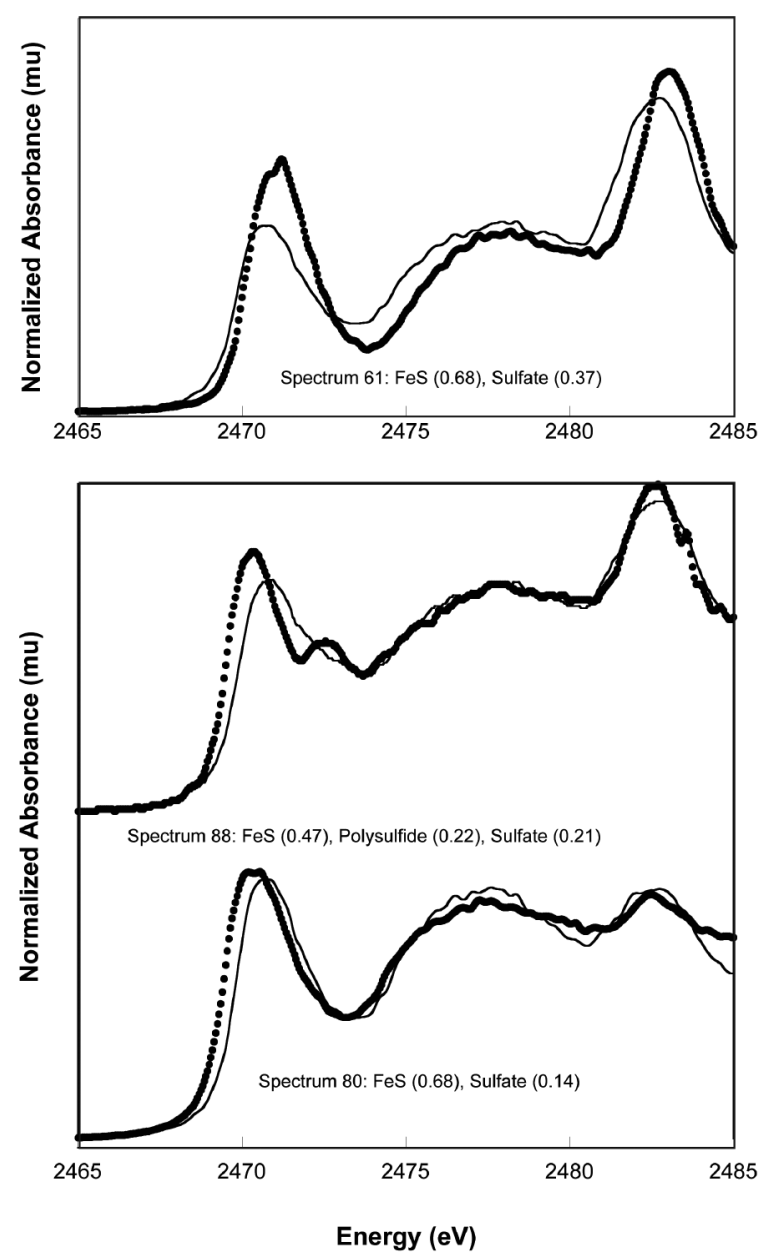

FIGURE 3. (top) $\mathrm{S}$ XANES spectra from oxically embedded $\mathrm{FeS}_{\mathrm{m}}$ compared to the same sample embedded anoxically (bottom). Data are black circles, and fits are thin black lines. with added Ni was fit with mostly FeS and some pyrrhotite.

The synthesized $\mathrm{FeS}_{\mathrm{m}}$ was sensitive to oxidation during embedding, polishing, and oxic handling during analysis. Figure 3 shows the EM S XANES spectrum of the $\mathrm{FeS}_{\mathrm{m}}$ embedded oxically, which was fit by the reference spectra for FeS (0.68) and sulfate (0.37) (Table 1). The EM spectra from $\mathrm{FeS}_{\mathrm{m}}$ embedded anoxically also fit with $\mathrm{FeS}$ and sulfate, but polysulfide was also necessary for a good fit (Fig. 3; Table 1). No ME map was collected, so it was not possible to assess the distribution of the phases. However, these spectra were determined to be representative of the 10 individual XANES collected on each sample by a PCA in SIXPACK. The FeS $\mathrm{m}_{\mathrm{m}}$ with no metal sample was not analyzed at the $\mathrm{Fe} K$-edge.

The results of S $K$-edge XRF and S XANES mapping on samples treated with the sulfur oxidation method are presented in Figure 4, with the EM spectra displayed and used to determine phase distributions and the spectral fitting results reported in Table 1. The FeS $\mathrm{m}_{\mathrm{m}}$ with no metals added oxidized with the sulfur oxidation method resulted in predominately pyrite (Fig. 4a). Minor amounts of FeS were present in this and Co- and Nicontaining samples (Figs. $4 \mathrm{~b}$ and $4 \mathrm{c}$ ), visible as a shoulder at $2470 \mathrm{eV}$ along the pyrite pre-edge absorption feature. Sulfate was also present, as with $\mathrm{FeS}_{\mathrm{m}}$ samples. No sulfur was detected by XRF/XANES, although it was observed by XRD (Fig. 1). When Co was present, the grains were predominantly pyrite, with some polysulfide and residual FeS (Fig. 4b). The matrix was composed of sulfur and polysulfide, which was not seen in the metal-free sample. When Ni was added, most grains were made of pyrite with some polysulfide, or pyrite with FeS (Fig. 4c).

The $\mathrm{FeS}_{\mathrm{m}}$ containing either $\mathrm{Co}$ or $\mathrm{Ni}$ treated with the $\mathrm{H}_{2} \mathrm{~S}$ oxidation pathway did not produce pyrite, according to $S$ XANES and XRF. The composition of EM S XANES spectra determined fitting was FeS with minor sulfate (Table 1). The Fe XANES spectra fit with an FeS standard (Table 2).

\section{Trace element additions}

The elemental concentrations of solutions used to synthesize $\mathrm{FeS}_{\mathrm{m}}$ were analyzed, but $\mathrm{S}$ was not calibrated, and Fe was often above the range of the calibration curve and could not be quantified (Table 3). The ferrous ammonium sulfate solutions with nickel chloride or cobalt chloride were measured before adding the sodium sulfide solution and had a concentration of $65.28 \mathrm{mg} / \mathrm{L}(1112 \mu \mathrm{M}) \mathrm{Ni}$, which was diluted by an equal volume of sodium sulfide solution to achieve ca. $500 \mu \mathrm{M}$ Ni final

TABLE 2. Iron XANES fit data

\begin{tabular}{|c|c|c|c|c|c|c|c|c|c|}
\hline Sample & $\begin{array}{c}\text { Number of } \\
\text { spectra }\end{array}$ & $\begin{array}{l}\text { End-member } \\
\text { (EM) ID }\end{array}$ & FeS & Pyrite & Marcasite & Pyrrhotite & Maghemite & Comp. Sum & $\chi^{2}$ \\
\hline \multirow[t]{3}{*}{ Pyrite (2015) } & 10 & 15 & 1.01 & & & & & 1.01 & 1.55 \\
\hline & & 16 & & 0.62 & 0.40 & & & 1.02 & 0.05 \\
\hline & & 20 & 0.57 & 0.43 & & & & 1.00 & 2.91 \\
\hline $\mathrm{FeS}+\mathrm{Co}(2013)$ & 8 & 2 & 0.70 & & & 0.32 & & 1.03 & 0.49 \\
\hline $\mathrm{FeS}+\mathrm{Co} \mathrm{H}_{2} \mathrm{~S}$ (2013) & 8 & 5 & 1.04 & & & & & 1.04 & 0.59 \\
\hline \multirow[t]{3}{*}{ Pyrite + Co (2015) } & 10 & 53 & 0.99 & & & & & 0.99 & 1.20 \\
\hline & & 54 & & 0.99 & & & & 0.99 & 2.16 \\
\hline & & 58 & & 0.42 & 0.59 & & & 1.01 & 0.17 \\
\hline \multirow[t]{2}{*}{$\mathrm{FeS}+\mathrm{Ni}(2015)$} & 8 & 26 & 0.70 & & & 0.30 & & 1.00 & 0.24 \\
\hline & & 30 & 0.48 & & & 0.54 & & 1.02 & 1.06 \\
\hline $\mathrm{FeS}+\mathrm{Ni} \mathrm{H}_{2} \mathrm{~S}(2013)$ & 3 & 1 & 0.95 & & & & & 0.95 & 6.85 \\
\hline \multirow{2}{*}{ Pyrite + Ni (2014) } & 3 & 43 & & 0.83 & 0.14 & & & 0.97 & 0.93 \\
\hline & & 45 & & & 0.37 & & 0.51 & 0.87 & 9.11 \\
\hline
\end{tabular}



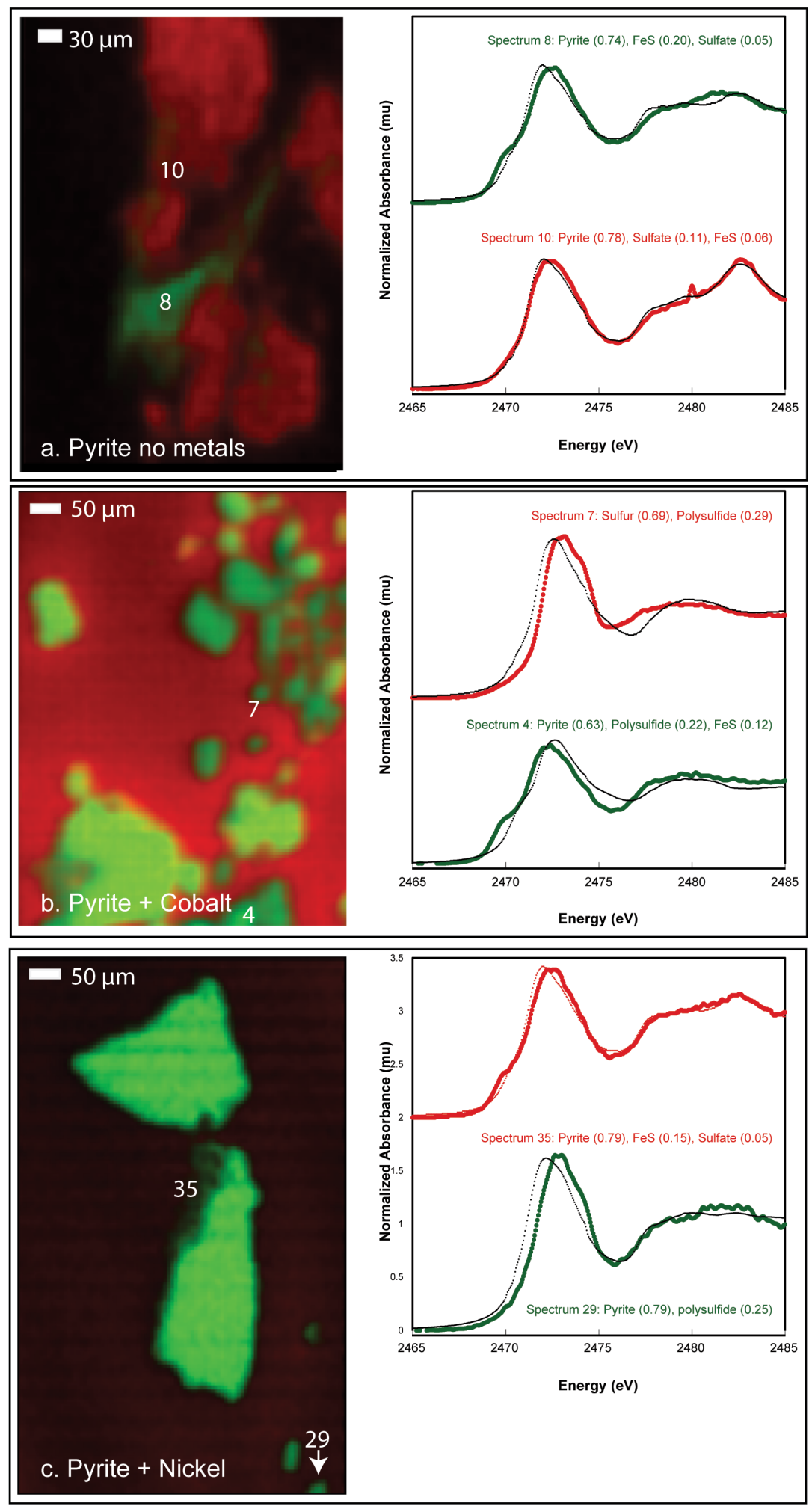

FIGURE 4. Phase distribution maps generated from multiple XRF maps within the $\mathrm{S} K$-edge and point XANES in experiments where pyrite was produced from sulfur oxidation. For each sample, the end-member XANES points labeled on the map (numbers) correspond to the spectra at right, and their distribution is shown in the same color as the corresponding spectra. Fits are dotted black lines. The fit compositions, as reported in Table 1, are also given. (a) Results of pyrite synthesis from $\mathrm{FeS}_{\mathrm{m}}$ with no metals added. (b) Results of pyrite synthesis from $\mathrm{FeS}_{\mathrm{m}}$ with $\mathrm{Co}$ added. (c) Results of pyrite synthesis from $\mathrm{FeS}_{\mathrm{m}}$ with $\mathrm{Ni}$ added. 
concentration. The solution with Co had $223.2 \mathrm{mg} / \mathrm{L}(3878 \mu \mathrm{M})$ $\mathrm{Co}$, and was also diluted by an equal volume of the sodium sulfide solution to achieve ca. $2000 \mu \mathrm{M}$ Co.

The Fe content of bulk solids determined with ICP-OES increased after applying the $\mathrm{H}_{2} \mathrm{~S}$ oxidation protocol (Table 3 ). The Fe content was only quantified in the Ni-containing sample after sulfur oxidation, due to the range of ICP-AES and standard concentrations. For the Co- and Ni-bearing solids, Co and $\mathrm{Ni}$ were quantified in bulk by either ICP-OES $\left(\mathrm{FeS}_{\mathrm{m}}\right.$ and $\mathrm{H}_{2} \mathrm{~S}$ oxidation samples) or ICP-AES (sulfur oxidation samples; Table 3 ) or semi-quantitatively mapped by X-ray fluorescence at $11 \mathrm{keV}$ on individual pixels (Table 4). The measured values of $\mathrm{Co}$ and $\mathrm{Ni}$ in $\mathrm{FeS}_{\mathrm{m}}$, measured by ICP-OES were $1.05 \pm 0.26 \mathrm{mg}$ Ni per $\mathrm{g} \mathrm{FeS}_{\mathrm{m}}$, and $3.71 \pm 0.06 \mathrm{mg}$ Co per $\mathrm{g} \mathrm{FeS}_{\mathrm{m}}$, higher than the range of the median values obtained by synchrotron-based XRF mapping on beamline $2-3$ at $11 \mathrm{keV}$ : of $0.4 \pm 0.2 \mathrm{mg} \mathrm{Ni}$ per $\mathrm{g} \mathrm{FeS}_{\mathrm{m}}$ and $3.1 \pm 0.7 \mathrm{mg}$ Co per $\mathrm{g} \mathrm{FeS}_{\mathrm{m}}$. Quantification of $\mathrm{Ni}$ after sulfur oxidation diverged the most between methods. ICP-AES measured $3.4 \pm 0.1 \mathrm{mg}$ Ni per g mineral, while XRF maps contained median values of $0.5 \pm 0.4 \mathrm{mg}$ Ni per $\mathrm{g}$ mineral. Results for Co after sulfur oxidation were comparable by bulk and microscale methods. Maps of particles used for XRF quantification are shown in Supplementary ${ }^{1}$ Figure S1.

\section{DISCUSSION}

\section{Mineral transformation}

For the $\mathrm{FeS}_{\mathrm{m}}$ synthesized in this study, XRD documented the mineral mackinawite, with minor greigite and pyrrhotite (Fig. 1). The best fitting standard for S XANES spectra was with FeS, a mackinawite standard, occasional polysulfide, and varying amounts of sulfate (Table 1). Even after embedding in the glovebox, the $\mathrm{FeS}_{\mathrm{m}}$ still shows signs of oxidation, shown by the inclusion of sulfate and polysulfide in the fits, although it may be less oxidized than samples embedded in the air (Fig. 3). Less sulfate was needed to fit the anoxically embedded samples, however, indicating some success of the protection from oxygen. The presence of polysulfide may have resulted from some sample hydration during storage, as the sample was anoxically embedded a year after oxically embedded samples, although they were stored under dry $\mathrm{N}_{2}$ in airtight containers. As sulfate minerals were not detected in XRD (detection limit $5 \mathrm{wt} \%$ ), oxidation likely occurred during the storage, embedding or analysis of samples, and not during synthesis or transformation protocols. There was a major reflection at about $35^{\circ}$ in the $\mathrm{FeS}_{\mathrm{m}}$ that could be greigite or pyrite, but other major reflections for these minerals were absent. The addition of Co or Ni did not appear to alter the mineralogy of the $\mathrm{FeS}_{\mathrm{m}}$, or to change the intensity or width of reflections (Fig. 1).

The attempts to transform $\mathrm{FeS}_{\mathrm{m}}$, with or without $\mathrm{Co}$ and/or $\mathrm{Ni}$, to pyrite via $\mathrm{H}_{2} \mathrm{~S}$ oxidation were not successful. From XRD, the sample still appeared to be mackinawite, with the most intense reflections in the Co-containing samples (Fig. 1). The Ni- and Co-containing samples were only reacted 4 days and yet had much more intense reflections for mackinawite than $\mathrm{FeS}_{\mathrm{m}}$ without metals, reacted either 4 or 20 days. The failure of the $\mathrm{H}_{2} \mathrm{~S}$ oxidation method to produce pyrite from $\mathrm{FeS}_{\mathrm{m}}$ synthesized with Co or Ni was also verified by S XANES and XRF mapping (Table 1), as well as by point Fe XANES analysis (Table 2). These results are consistent with several studies, which found very slow reactions between mackinawite and $\mathrm{H}_{2} \mathrm{~S}$ to form pyrite (Berner 1970; Schoonen and Barnes 1991b; Wilkin and Barnes 1996; Benning et al. 2000). It has been suggested that the freeze-dried FeS, used in the successful synthesis of pyrite via $\mathrm{H}_{2} \mathrm{~S}$ oxidation (Rickard 1997), underwent minor oxidation by oxygen during drying, providing oxidized surface sites for the formation of pyrite via reaction with $\mathrm{H}_{2} \mathrm{~S}$ (Benning et al. 2000). Secondary electron microscopy (SEM) studies of freeze-dried mackinawite in that second study noted an oxidized sulfate mineral phase, as well as a change in morphology from freshly precipitated mackinawite (Benning et al. 2000). In this same study, the freeze-dried material produced pyrite in reaction with $\mathrm{H}_{2} \mathrm{~S}(100 \%$ transformation after 9 days),

TABLE 4. Semi-quantitiative $\mathrm{Co}$ and $\mathrm{Ni}$ concentrations determined from XRF maps

\begin{tabular}{lcccc}
\hline Solids (mg element/g mineral) & Element & Mean & Median & e.s.d. \\
\hline FeS+Co (2013) & $\mathrm{Co}$ & 4 & 3.6 & 1.6 \\
$\mathrm{FeS}+\mathrm{Ni}(2013)$ & $\mathrm{Ni}$ & 0.5 & 0.4 & 0.3 \\
$\mathrm{FeS}+\mathrm{Co}+\mathrm{H}_{2} \mathrm{~S}(2013)$ & $\mathrm{Co}$ & 3.2 & 3.1 & 0.7 \\
$\mathrm{FeS}+\mathrm{Ni}+\mathrm{H}_{2} \mathrm{~S}(2013)$ & $\mathrm{Ni}$ & 0.5 & 0.4 & 0.2 \\
Pyrite+Co $(2014)$ & $\mathrm{Co}$ & 1.6 & 1.3 & 0.5 \\
Pyrite+Ni $(2014)$ & $\mathrm{Ni}$ & 0.6 & 0.5 & 0.4 \\
\hline
\end{tabular}

Analytical precision was $0.1 \mathrm{mg}$ element/g FeS $\mathrm{m}_{\text {, }}$ which is estimated as the detection limit.

TABLE 3. Elemental concentrations as determined on digests by ICP-OES or ICP-AES

\begin{tabular}{|c|c|c|c|}
\hline ICP-OES & $\mathrm{Fe}$ & Co & $\mathrm{Ni}$ \\
\hline & \multicolumn{3}{|c|}{ Solutions (ppm) } \\
\hline Ferrous ammonium sulfate $(0.6 \mathrm{M})$ & NA & $1.36 \pm 2.36$ & $4.39 \pm 1.37$ \\
\hline Hydrogen sulfide $(0.6 \mathrm{M})$ & $1.67 \pm 8.86$ & $\mathrm{BD}$ & BD \\
\hline Ferrous ammonium sulfate $(0.6 \mathrm{M})$ with $2 \mathrm{mM}$ Co & NA & $223.20 \pm 0.33$ & $4.40 \pm 0.84$ \\
\hline \multirow[t]{2}{*}{ Ferrous ammonium sulfate $(0.6 \mathrm{M})$ with $0.5 \mathrm{mM} \mathrm{Ni}$} & NA & $1.47 \pm 0.41$ & $65.28 \pm 0.97$ \\
\hline & \multicolumn{3}{|c|}{ Solids (mg element/g mineral) } \\
\hline FeS no metals & $327.53 \pm 0.23$ & $0.02 \pm 0.02$ & $0.05 \pm 0.630$ \\
\hline $\mathrm{FeS}+\mathrm{Co}$ & $348.56 \pm 0.07$ & $3.71 \pm 0.06$ & $0.07 \pm 0.11$ \\
\hline $\mathrm{FeS}+\mathrm{Ni}$ & $319.23 \pm 0.36$ & $0.023 \pm 0.26$ & $1.05 \pm 0.26$ \\
\hline FeS no metals $\mathrm{H}_{2} \mathrm{~S}$ ( 20 days) & $480.87 \pm 2.60$ & $0.05 \pm 6.45$ & $0.06 \pm 22.15$ \\
\hline FeS no metals $\mathrm{H}_{2} \mathrm{~S}$ (4 days) & $483.14 \pm 1.65$ & $0.03 \pm 10.04$ & $0.027 \pm 68.14$ \\
\hline $\mathrm{FeS}+\mathrm{Co} \mathrm{H}_{2} \mathrm{~S}$ & $455.96 \pm 0.85$ & $4.05 \pm 1.92$ & $0.06 \pm 2.82$ \\
\hline $\mathrm{FeS}+\mathrm{Ni} \mathrm{H}_{2} \mathrm{~S}$ & $493.71 \pm 1.13$ & $0.05 \pm 0.40$ & $1.43 \pm 0.87$ \\
\hline Pyrite no metals & NA & $\mathrm{BD}$ & $\mathrm{BD}$ \\
\hline Pyrite+Co & NA & $1.1 \pm 0.0$ & $\mathrm{BD}$ \\
\hline Pyrite+Ni & $327.7 \pm 20.4$ & BD & $3.4 \pm 0.1$ \\
\hline
\end{tabular}

Notes: $\mathrm{NA}=$ element was either not quantified, or element was above the range of quantification. $\mathrm{BD}=$ below detection. Detection limits were $0.0008,0.0011$, and $0.0015 \mathrm{ppm}$ for $\mathrm{Fe}, \mathrm{Co}$, and $\mathrm{Ni}$, respectively, for ICP-OES. Detection limits were $0.1,0.1$, and $0.2 \mathrm{ppm}$ for $\mathrm{Fe}$, $\mathrm{Co}$, and Ni, respectively for ICP-AES. The relative standard deviations are also reported. 
whereas freshly precipitated mackinawite reacted with $\mathrm{H}_{2} \mathrm{~S}$ did not. Our finding that $\mathrm{N}_{2}$-dried mackinawite does not react with $\mathrm{H}_{2} \mathrm{~S}$ to form pyrite further support the claim (i.e., Benning et al. 2000) that $\mathrm{H}_{2} \mathrm{~S}$ oxidation of mackinawite is not a significant reaction in the formation of pyrite at low temperatures.

In contrast, pyrite was formed from the sulfur oxidation method, evident in clear reflections for pyrite from XRD in metalfree samples (Fig. 1). After pyritization, most XRD reflections for mackinawite had disappeared, indicating a near-complete reaction. From the S ME mapping and EM XANES, pyrite was also the main product (Fig. 4; Table 1), with minor FeS and sulfate, likely reflecting oxidation during sample mounting and/or analysis (e.g., Fig. 2). The spot Fe XANES analysis also documented pyrite, but the product still retained some $\mathrm{FeS}_{\mathrm{m}}$ (Table 4). In addition, marcasite was a component of Fe XANES fits (Table 4), which likely reflects the same sulfur oxidation state and similar orbital energy levels of $\mathrm{Fe}$ in pyrite and marcasite (Jones 2006), rather than the presence of marcasite. The Fe XANES of pyrite and marcasite are very similar (O'Day et al. 2004). The inclusion of pyrrhotite in some fits could reflect some oxidation during embedding, storage, or analysis.

Pyrite was also produced in the Co-containing solids, as shown by XRD, S XANES, and Fe XANES. In the Co-containing samples, an additional intense reflection for sulfur was present at about $26^{\circ}$, and several minor reflections between $30-35^{\circ}$ in the XRD data (Fig. 1). These likely correspond to residual sulfur retained after $\mathrm{CS}_{2}$ washing. The single $\mathrm{CS}_{2}$ wash must have been insufficient to remove sulfur. It is significant that evidence for residual sulfur is not seen in the metal-free product. In Co-containing samples analyzed by $\mathrm{S}$ XANES, FeS was still present in pyrite grains (visible as a shoulder at $2470 \mathrm{eV}$ ), as was polysulfide (Fig. 4). Sulfur and polysulfide comprised the matrix, consistent with the intense reflections for sulfur by XRD. Polysulfides form in the reaction of elemental sulfur with water, and themselves react with $\mathrm{FeS}_{\mathrm{m}}$ to form pyrite (Schoonen and Barnes 1991b), and so are expected $S$ phases during pyrite formation by the $\mathrm{S}^{0}$ oxidation method. By Fe XANES, both pyrite/marcasite and FeS were components of fits. Taken together, these data indicate that the presence of Co impeded reaction of $\mathrm{FeS}_{\mathrm{m}}$ to pyrite in the time course of the experiments (2 weeks). Although $\mathrm{FeS}_{\mathrm{m}}$ was still detectable in metal-free product, the absence of any detectable sulfur may signify that metal-free $\mathrm{FeS}_{\mathrm{m}}$ reacted more completely than Co-amended $\mathrm{FeS}_{\mathrm{m}}$. Inhibition of FeS transformation to pyrite has been observed in the presence of arsenate $[\mathrm{As}(\mathrm{V})]$, although this is linked to arsenate oxidizing both $\mathrm{Fe}$ and $\mathrm{S}$ (Wolthers et al. 2007). An analogous pathway can be excluded for $\mathrm{Co}^{2+}$, as its reduction in the aqueous phase is unlikely. Arsenate and arsenite ([As(III)] can also prevent FeS transformation to pyrite by sorption and blockage of surface sites (Wolthers et al. 2007). Although, Co does not adsorb even as strongly to FeS as Ni (Morse and Arakaki 1993), yet Ni-containing FeS appears to have more completely reacted in our experiments (see below). The lower concentrations of Co in pyrite compared to FeS (Tables 3 and 4) indicate that some Co could have been mobilized from solid phases during the reaction and available for sorption. It is impossible to rule out inhibition of pyrite formation due to Co sorption with our data.

For Ni-containing samples, the predominant product of sulfur oxidation was pyrite, based on XRD, S XANES, and Fe XANES analyses. Some residual $\mathrm{FeS}_{\mathrm{m}}$ was present based on $\mathrm{S}$ and $\mathrm{Fe}$ XANES (Tables 1 and 2). One Fe XANES EM also fit with maghemite, indicating Fe oxidation, which likely occurred during sample embedding, storage, or analysis, as it was not detected by XRD prior to these steps. Sulfur was also present based on $\mathrm{XRD}$, but the diffraction peaks were not as sharp or as large as for the Co-containing product. Polysulfide was detectable in $\mathrm{S}$ XANES (Fig. 4). The reaction of $\mathrm{FeS}_{\mathrm{m}}$ to pyrite also seems to be incomplete in the presence of $\mathrm{Ni}$, but may have progressed further given the evidence for more abundant sulfur/polysulfide in the Co-containing grains. Another line of evidence is the more abundant distribution of sulfur-rich grains in Co-containing product, as revealed by the 8000 eV XRF map (Supplementary ${ }^{1}$ Fig. S2) as compared to the Ni-containing product, although the sample size is just a few grains.

These results of incomplete pyrite formation in Ni-containing samples are in contrast to the recent observation that the presence of $\mathrm{Ni}$ accelerates the rate of pyrite formation (Morin et al. 2017). In that work, pyrite was formed from de novo synthesis from slightly acidic (ca. $\mathrm{pH}=5.5$ ) solutions of ferric chloride and $\mathrm{H}_{2} \mathrm{~S}$ (Noël et al. 2014, 2015). In this mechanism, Fe(III) must be the oxidant, whereas our protocol started with solid $\mathrm{FeS}_{\mathrm{m}}$ and utilized sulfur as the oxidant. The authors proposed that Ni impurities accelerated pyrite nucleation from solution (Morin et al. 2017), which is generally slow. However, formation of pyrite in marine sediments likely proceeds from the nucleation and subsequent sulfidization of FeS minerals, such as mackinawite and greigite (Schoonen and Barnes 1991a), rather than through reaction of aqueous Fe(III) and $\mathrm{H}_{2} \mathrm{~S}$. This inference is supported by the observation of FeS phases being converted to pyrite with depth in numerous anoxic sediments (Cutter and Velinsky 1988; Huerta-Diaz and Morse 1992; Scholz and Neumann 2007). Our experiments, therefore, suggest that $\mathrm{Ni}$ (and $\mathrm{Co}$ ) impurities might impede the rate of pyritization in $\mathrm{pH}$ circum-neutral sediments, although others note that Ni and Co may more completely pyritize than other metals (Morgan et al. 2012b).

The weight percent of $\mathrm{Fe}$ in $\mathrm{FeS}_{\mathrm{m}}$ calculated from bulk digestion data in Table 3 was about $30-40 \%$, less than the predicted $63.5 \%$ for a $1: 1 \mathrm{Fe}: \mathrm{S}$ stoichiometry. This lower weight percent iron may have been caused by sulfate precipitation during drying, as discussed above. After the $\mathrm{H}_{2} \mathrm{~S}$ oxidation protocol, the weight percent of iron increased to $42-51 \%$, closer to stoichiometric FeS, but still lower than expected. This may be due to increasing crystallinity of the $\mathrm{FeS}_{\mathrm{m}}$ in the aqueous phase (Rickard 1995), which has support from the sharpening of diffraction peaks (Fig. 1) or washing out of excess sulfate with the fluids used for $\mathrm{H}_{2} \mathrm{~S}$ oxidation. Although the Fe content was not determined on most solids produced by the sulfur oxidation protocol, the Fe content for pyrite for the Ni-containing sample was ca. $33 \mathrm{wt} \%$, whereas stoichiometric pyrite should have $46.55 \% \mathrm{Fe}$. This likely reflects residual sulfur in the solid sample after the sulfur oxidation method, as well as the persistence of $\mathrm{FeS}_{\mathrm{m}}$.

\section{Trace element incorporation}

The distribution coefficient for $\mathrm{Co}$ in $\mathrm{FeS}_{\mathrm{m}}$ at $25^{\circ} \mathrm{C}$ is $29 \pm 3$ (Morse and Arakaki 1993), which predicted $16 \pm 2 \mathrm{mg}$ Co per $\mathrm{g}$ $\mathrm{FeS}_{\mathrm{m}}$ in our synthesized mineral. The measured values of Co were 2.6 to $3.7 \mathrm{mg}$ Co per $\mathrm{g}$ mineral were well under this range. Based on the published distribution coefficient of $280 \pm 181$ for $\mathrm{Ni}$ in 
$\mathrm{FeS}_{\mathrm{m}}$ at $25^{\circ} \mathrm{C}$ (Morse and Arakaki 1993), we expected to see 3.9 $\pm 2.5 \mathrm{mg}$ Ni per $\mathrm{g} \mathrm{FeS}_{\mathrm{m}}$. The measured value of $\mathrm{Ni}$ in $\mathrm{FeS}_{\mathrm{m}}(0.6$ to $1.05 \mathrm{mg}$ Ni per g mineral) was below this range (Table 3 ). In those experiments, mackinawite was synthesized by slow titration, whereas our $\mathrm{FeS}_{\mathrm{m}}$ was synthesized rapidly by mixing a Co- or Ni-bearing iron solution with a sulfide solution. It is likely that this fast precipitation did not allow full uptake of the likely equilibrium values of $\mathrm{Co}$ and $\mathrm{Ni}$ observed in slow precipitation experiments (Morse and Arakaki 1993). This may be due to the slower exchange of $\mathrm{H}_{2} \mathrm{O}$ ligand for $\mathrm{S}^{2-}$ on $\mathrm{Co}^{2+}$ and $\mathrm{Ni}^{2+}$ ions as compared to $\mathrm{Fe}^{2+}$ ions (Morse and Luther 1999).

After the $\mathrm{H}_{2} \mathrm{~S}$ oxidation protocol, the measured value was $4.05 \pm 1.92 \mathrm{mg}$ Co per $\mathrm{g}$ mineral, and $1.1 \mathrm{mg}$ Co per $\mathrm{g}$ mineral after the sulfur oxidation protocol. Cobalt enrichments in $\mathrm{FeS}_{\mathrm{m}}$ are generally present in all particles based on XRF mapping of the synthesized minerals at $8500 \mathrm{eV}$ (Supplementary ${ }^{1}$ Fig. S2). In the samples mapped after sulfur oxidation, Co was distributed throughout the Fe-rich particles. From cross-plots of the Fe and $\mathrm{S}$ pixels, the Fe-rich particles always contain some $\mathrm{S}$, and so are inferred to be $\mathrm{FeS}_{\mathrm{m}}$ /pyrite. The sulfur-rich grains comprise a very low-Fe population of pixels and are likely sulfur/polysulfide-rich grains (analyses not shown). Cobalt is visible in the $\mathrm{FeS}_{\mathrm{m}}$ /pyrite grains, but absent in the sulfur/polysulfide grains, indicating that Co is preferentially incorporated into sulfide minerals. From the bulk (ICP-OES or ICP-AES) and XRF metal quantification, there was general agreement between the techniques for the quantity of $\mathrm{Co}$ in both $\mathrm{FeS}_{\mathrm{m}}$ and sulfur oxidation products (Fig. 5). However, Co was quantitatively lost from the samples during transformation. The lower concentration of Co in Fe-rich particles by XRF after pyrite transformation (Supplementary ${ }^{1}$ Figs. S1 and S2) indicates this is not a phenomenon of solid-phase dilution with residual sulfur for the ICP analyses. Therefore, it seems likely that Co is lost from the sulfide phase during the transformation of $\mathrm{FeS}_{\mathrm{m}}$ to pyrite.

After treating $\mathrm{FeS}_{\mathrm{m}}$ with the $\mathrm{H}_{2} \mathrm{~S}$ oxidation protocol, Ni increased to $1.43 \pm 0.87 \mathrm{mg}$ Ni per $g$ mineral. The amount in pyrite produced from the sulfur oxidation protocol was $3.4 \pm 0.1 \mathrm{mg} \mathrm{Ni}$ per $g$ mineral. In Ni-containing samples, the $\mathrm{FeS}_{\mathrm{m}}$ has $\mathrm{Ni}$ distributed throughout all grains. In the Ni-containing product oxidized by sulfur, both $\mathrm{S}$ - and Fe-rich grains are visible in the XRF map, similar to the Co-containing sample (Supplementary ${ }^{1}$ Fig. S2). In the product, some Fe-rich grains are preferentially enriched in $\mathrm{Ni}$, while others are Ni-poor, distinct from the Co-rich product. The S-rich grains have little Ni. As no multi-energy maps were made at these higher energies on BL2-3 (e.g., the Fe $K$-edge), it is not possible to say whether Ni preferentially incorporated into discrete iron sulfide phases, such as $\mathrm{FeS}_{\mathrm{m}}$ or pyrite. Other studies have documented a preference of $\mathrm{Ni}$ for the

FIGURE 6. Overplots of end-member $\mathrm{FeS}_{\mathrm{m}}$ and pyrite $\mathrm{S}$ XANES from samples synthesized with and without $\mathrm{Co}$ and $\mathrm{Ni}$. The presence of Ni causes a shift for the pre-edge feature of $\mathrm{FeS}_{\mathrm{m}}$ and pyrite to be shifted to higher energy. A subtle shift is observed with Co, but only for $\mathrm{FeS}_{\mathrm{m}}$.

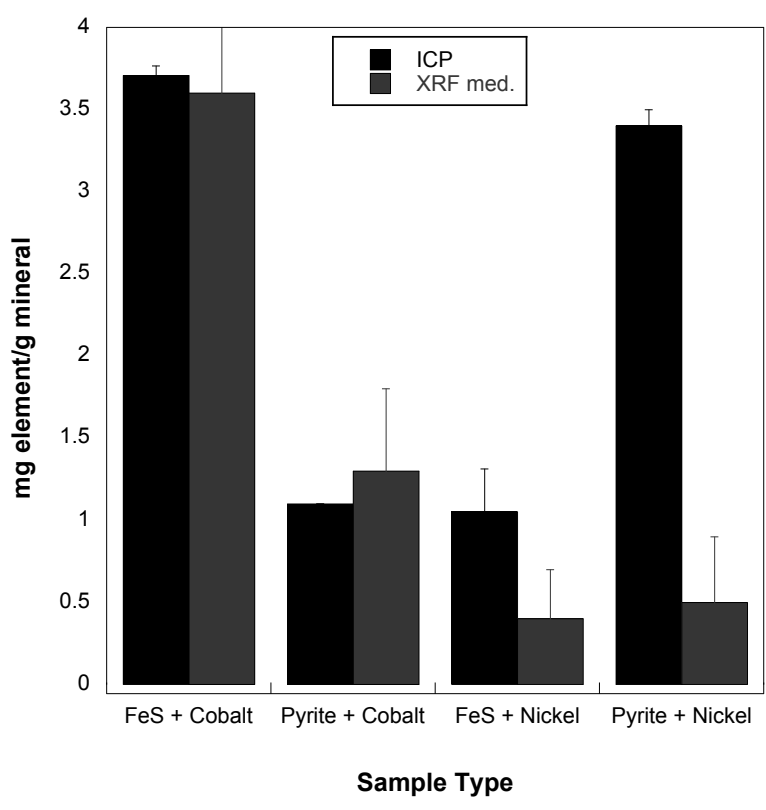

FigURE 5. Amount of metal in the solids produced from $\mathrm{FeS}_{\mathrm{m}}$ and pyrite synthesis in the presence of $\mathrm{Co}$ or $\mathrm{Ni}$. The average of triplicate bulk measurements by ICP-AES or ICP-OES are in black, with error bars representing the standard deviation. The median of individual pixels in grains determined on XRF maps collected at $8500 \mathrm{eV}$. The error bars are the standard deviation of these data.

pyrite vs. mackinawite mineral (Noël et al. 2015). This may be consistent with preferential $\mathrm{Ni}$ concentration in pyrite-bearing grains, as opposed to $\mathrm{FeS}_{\mathrm{m}}$ grains, although we cannot validate this with the current data set. The ICP data always detected more $\mathrm{Ni}$ in the samples than is apparent with the synchrotron-based XRF maps (Fig. 5), likely indicating the need for further matrix correction for XRF standards. Both techniques show an increase of $\mathrm{Ni}$ in the solid after sulfur oxidation, although this increase is unlikely to be statistically significant in the XRF data. It is possible that in the case of dissolution of FeS, and incomplete pyrite formation, mobilized $\mathrm{Ni}$ was effectively sequestered in fewer grains, increasing the concentration.

A final observation is that the addition of Co or Ni shifted the pre-edge peak position of the FeS in the S XANES spectra to
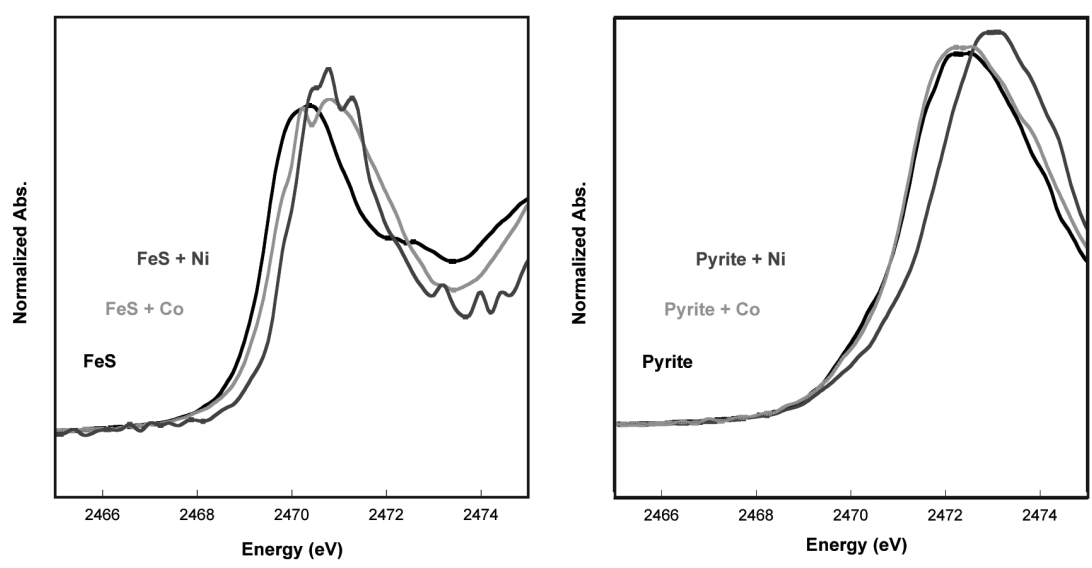
more positive values (Fig. 6), which was more extreme for Ni. A similar peak shift was noted for pyrite, although only for Ni. Other authors noted longer bond distance $(2.28 \AA$ ) for Ni-S than for $\mathrm{Fe}-\mathrm{S}$ $(2.26 \AA)$ based on Ni EXAFS of mackinawite synthesized with Ni (Wilkin and Beak 2017). However, shorter bond distances generally require higher excitation energy. It may more likely reflect the ordering of stability constants of the transition metal series, e.g., the Irving-Williams order, $\mathrm{Fe}<\mathrm{Co}<\mathrm{Ni}<\mathrm{Cu}>\mathrm{Zn}$ (Rickard and Luther 2006). Although the amount of the non-Fe metal is small, these pre-edge peaks may reflect the increased energy needed to achieve electronic transitions to empty hybridized Me-S and S-S anti-bonding orbitals.

\section{IMPLICATIONS}

The experiments described herein attempt to determine how efficiently the trace metals $\mathrm{Ni}$ and $\mathrm{Co}$ are pyritized under lowtemperature pyrite formation from mackinawite. A first and important result was that oxidation of $\mathrm{FeS}_{\mathrm{m}}$ by $\mathrm{H}_{2} \mathrm{~S}$ did not produce pyrite, casting doubt on the validity of this as a pyrite formation pathway in the absence of oxidized surface sites. However, pyrite was successfully synthesized through oxidation of $\mathrm{FeS}_{\mathrm{m}}$ with elemental sulfur. The equilibrium concentration of $\mathrm{Co}$ and $\mathrm{Ni}$ in the initial $\mathrm{FeS}_{\mathrm{m}}$ predicted by the published distribution coefficients was not attained in our experiments due to the fast precipitation method used. Cobalt was lost from the solid during transformation, as shown by the diminished concentrations of Co in pyrite compared to $\mathrm{FeS}_{\mathrm{m}}$. The concentration of Ni increased during transformation, possibly due to the dissolution of $\mathrm{FeS}_{\mathrm{m}}$ and preferential sequestration of $\mathrm{Ni}$ in pyrite. In both cases, pyrite formation was not complete in the presence of added metals, indicating a kinetic inhibition to the formation of pyrite in the presence of Co and $\mathrm{Ni}$. Taken together, these results suggest that if the pyrite formation pathway can be determined to initiate from a precursor FeS phase, the concentration of $\mathrm{Co}$ in pyrite could serve as a conservative record of environmental concentrations. Nickel, however, seems unreliable in this capacity, as pyrite appears to take up additional $\mathrm{Ni}$ in comparison to precursor $\mathrm{FeS}_{\mathrm{m}}$, during its formation, as well as incorporate in other phases, such as elemental sulfur. A caveat of this work is that other pyrite formation mechanisms are possible, e.g., from another solid-phase precursor mineral such as greigite or by reductive dissolution of Fe(III) (oxyhydr)oxides with hydrogen sulfide or an aqueous or colloidal species (e.g., $\mathrm{FeS}_{\mathrm{aq}}$ ), and the fate of trace metals during transformation should also be evaluated under those conditions. Also, our results are specific only to $\mathrm{Co}$ and $\mathrm{Ni}$, and should not be extrapolated to other metals.

\section{FUNDING}

This work was funded by a Deutsche Forschungsgemeinschaft grant (KA 1736/24-1). Use of the Stanford Synchrotron Radiation Lightsource, SLAC National Accelerator Laboratory, is supported by the U.S. Department of Energy, Office of Science, Office of Basic Energy Sciences under Contract No. DE-AC02$76 \mathrm{SF} 00515$.

\section{ACKNOWLEDGMENTS}

We thank Ellen Roehm for performing BET, Mastersizer, and ICP-AES analysis of samples. James Byrne and Maximilian Halama analyzed samples by $\mu$ XRD. Stefan Peiffer and Mali Wan gave helpful advice regarding the synthesis of pyrite. Tabea Schmid and Bertrand Ligous assisted in developing and performing the epoxy embedding and polishing of samples. The polysulfide standard was a gift of Greg Druschel and Fotios Kafantaris. Sümeyya Eroglu, Maximilian Halama, and Aude Picard assisted with measurements at the SSRL. Courtney Roach assisted with beamline optimization and data interpretation.

\section{REFERENCES CITED}

Algeo, T.J., and Maynard, J.B. (2004) Trace-element behavior and redox facies in core shales of Upper Pennsylvanian Kansas-type cyclothems. Chemical Geology, 206, 289-318.

Algeo, T.J., and Rowe, H. (2012) Paleoceanographic applications of trace-metal concentration data. Chemical Geology, 324-325, 6-18.

Anbar, A.D., and Knoll, A.H. (2002) Proterozoic ocean chemistry and evolution: A bioinorganic bridge? Science, 297, 1137-1142.

Benning, L.G., Wilkin, R.T., and Barnes, H.L. (2000) Reaction pathways in the Fe-S system below $100^{\circ} \mathrm{C}$. Chemical Geology, 167, 25-51.

Berner, R.A. (1970) Sedimentary pyrite formation. American Journal of Science, 286, 1-23.

Berthold, C., Bjeoumikhov, A., and Brügemann, L. (2009) Fast XRD2 microdiffraction with focusing X-ray microlenses. Particle \& Particle Systems Characterization, 26, 107-111.

Burton, E.D., Bush, R.T., Sullivan, L.A., Hocking, R.K., Mitchell, D.R.G., Johnston, S.G., Fitzpatrick, R.W., Raven, M., McClure, S., and Jang, L.Y. (2009) Iron-monosulfide oxidation in natural sediments: Resolving microbially mediated S transformations using XANES, electron microscopy, and selective extractions. Environmental Science \& Technology, 43, 3128-3134.

Butler, I.B., and Rickard, D. (2000) Framboidal pyrite formation via the oxidation of iron (II) monosulfide by hydrogen sulphide. Geochimica et Cosmochimica Acta, 64, 2665-2672.

Canfield, D.E., and Farquhar, J. (2009) Animal evolution, bioturbation, and the sulfate concentration of the oceans. Proceedings of the National Academy of Sciences, 106, 8123-8127.

Chappaz, A., Lyons, T.W., Gregory, D.D., Reinhard, C.T., Gill, B.C., Li, C., and Large, R.R. (2014) Does pyrite act as an important host for molybdenum in modern and ancient euxinic sediments? Geochimica et Cosmochimica Acta, 126, 112-122.

Chi Fru, E., Rodríguez, N.P., Partin, C.A., Lalonde, S.V., Andersson, P., Weiss, D.J., El Albani, A., Rodushkin, I., and Konhauser, K.O. (2016) Cu isotopes in marine black shales record the Great Oxidation Event. Proceedings of the National Academy of Sciences, 113, 4941-4946.

Cutter, G.A., and Velinsky, D.J. (1988) Temporal variations of sedimentary sulfur in a Delaware salt marsh. Marine Chemistry, 23, 311-327.

Dupont, C.L., Yang, S., Palenik, B., and Bourne, P.E. (2006) Modern proteomes contain putative imprints of ancient shifts in trace metal geochemistry. Proceedings of the National Academy of Sciences, 103, 17,822-17,827.

Dupont, C.L., Butcher, A., Valas, R.E., Bourne, P.E., and Caetano-Anollés, G. (2010) History of biological metal utilization inferred through phylogenomic analysis of protein structures. Proceedings of the National Academy of Sciences, 107, $10,567-10,572$.

Fakhraee, M., Crowe, S.A., and Katsev, S. (2018) Sedimentary sulfur isotopes and Neoarchean ocean oxygenation. Science Advances, 4, e1701835.

Farfan, G.A., Apprill, A., Webb, S.M., and Hansel, C.M. (2018) Coupled X-ray fluorescence and X-ray absorption spectroscopy for microscale imaging and identification of sulfur species within tissues and skeletons of scleractinian corals. Analytical Chemistry, 90, 12,559-12,566.

Frierdich, A.J., Luo, Y., and Catalano, J.G. (2011) Trace element cycling through iron oxide minerals during redox-driven dynamic recrystallization. Geology, 39, 1083-1086.

Goldhaber, M.B., and Kaplan, I.R. (1974) The sulfur cycle. In E.D. Goldberg, Ed., The Sea Vol. 5, pp. 569-655. Wiley-Interscience.

Gregory, D.D., Large, R.R., Halpin, J.A., Baturina, E.L., Lyons, T.W., Wu, S., Danyushevsky, L., Sack, P.J., Chappaz, A., Maslennikov, V. V., and others. (2015) Trace element content of sedimentary pyrite in black shales. Economic Geology, 110, 1389-1410.

Harrison, W., Pevear, D., and Lindahl, P. (1973) Trace Elements in Pyrites of the Green River Formation Oil Shales, Wyoming, Utah, and Colorado. In M. Tuttle, Ed., Geochemical, Biogeochemical, and Sedimentological Studies of the Green River Formation, Wyoming, Utah, and Colorado pp. D1-D23. U.S. Geological Survey.

Hellige, K., Pollok, K., Larese-Casanova, P., Behrends, T., and Peiffer, S. (2012) Pathways of ferrous iron mineral formation upon sulfidation of lepidocrocite surfaces. Geochimica et Cosmochimica Acta, 81, 69-81.

Holland, H.D. (1984) The Chemical Evolution of the Atmosphere and Oceans. Princeton University Press, New Jersey.

Huerta-Diaz, M.A., and Morse, J.W. (1990) A quantitative method for determination of trace metal concentrations in sedimentary pyrite. Marine Chemistry, 29, 119-144.

(1992) Pyritization of trace metals in anoxic marine sediments. Geochimica et Cosmochimica Acta, 56, 2681-2702.

Hunger, S., and Benning, L.G. (2007) Greigite: a true intermediate on the polysulfide pathway to pyrite. Geochemical Transactions, 8,1 .

Jones, R.T. (2006) Electronic structures of the sulfide minerals sphalerite, wurtzite, pyrite, marcasite, and chalcopyrite. Ph.D. thesis, University of South Australia.

Jørgensen, B.B. (1982) Mineralization of organic matter in the sea bed--the role of sulphate reduction. Nature, 296, 643.

Keene, A.F., Johnston, S.G., Bush, R.T., Sullivan, L.A., Burton, E.D., McElnea, A.E., Ahern, C.R., and Powell, B. (2011) Effects of hyper-enriched reactive Fe 
on sulfidization in a tidally inundated acid sulfate soil wetland. Biogeochemistry, 103, 263-279.

Konhauser, K.O., Pecoits, E., Lalonde, S.V., Papineau, D., Nisbet, E.G., Barley, M.E., Arndt, N.T., Zahnle, K., and Kamber, B.S. (2009) Oceanic nickel depletion and a methanogen famine before the Great Oxidation Event. Nature, 458, 750-753.

Konhauser, K.O., Lalonde, S. V., Planavsky, N.J., Pecoits, E., Lyons, T.W., Mojzsis, S.J., Rouxel, O.J., Barley, M.E., Rosiere, C., Fralick, P.W., and others. (2011) Aerobic bacterial pyrite oxidation and acid rock drainage during the Great Oxidation Event. Nature, 478, 369-373.

Kraal, P., Burton, E.D., and Bush, R.T. (2013) Iron monosulfide accumulation and pyrite formation in eutrophic estuarine sediments. Geochimica et Cosmochimica Acta, 122, 75-88.

Large, R.R., Danyushevsky, L., Hollit, C., Maslennikov, V., Meffre, S., Gilbert, S., Bull, S., Scott, R., Emsbo, P., Thomas, H., and others. (2009) Gold and Trace Element Zonation in Pyrite Using a Laser Imaging Technique: Implications for the Timing of Gold in Orogenic and Carlin-Style Sediment-Hosted Deposits. Economic Geology, 104, 635-668.

Large, R.R., Halpin, J.A., Danyushevsky, L.V., Maslennikov, V.V., Bull, S.W., Long, J.A., Gregory, D.D., Lounejeva, E., Lyons, T.W., Sack, P.J., and others. (2014) Trace element content of sedimentary pyrite as a new proxy for deep-time ocean-atmosphere evolution. Earth and Planetary Science Letters, 389, 209-220.

Long, J.A., Large, R.R., Lee, M.S.Y., Benton, M.J., Danyushevsky, L.V., Chiappe, L.M., Halpin, J.A., Cantrill, D., and Lottermoser, B. (2016) Severe selenium depletion in the Phanerozoic oceans as a factor in three global mass extinction events. Gondwana Research, 36, 209-218.

Luther, G.W., and Rickard, D.T. (2005) Metal sulfide cluster complexes and their biogeochemical importance in the environment. Journal of Nanoparticle Research, 7, 389-407.

Mayhew, L.E., Webb, S.M., and Templeton, A.S. (2011) Microscale Imaging and Identification of Fe Speciation and Distribution during Fluid-Mineral Reactions under Highly Reducing Conditions. Environmental Science \& Technology, 45, 4468-4474.

Mojzsis, S.J., Coath, C.D., Greenwood, J.P., McKeegan, K.D., and Harrison, T.M. (2003) Mass-independent isotope effects in Archean (2.5 to $3.8 \mathrm{Ga}$ ) sedimentary sulfides determined by ion microprobe analysis. Geochimica et Cosmochimica Acta, 67, 1635-1658.

Morgan, B., Burton, E.D., and Rate, A.W. (2012a) Iron monosulfide enrichment and the presence of organosulfur in eutrophic estuarine sediments. Chemical Geology, 296-297, 119-130.

Morgan, B., Rate, A.W., and Burton, E.D. (2012b) Trace element reactivity in FeSrich estuarine sediments: Influence of formation environment and acid sulfate soil drainage. Science of the Total Environment, 438, 463-476.

Morin, G., Noël, V., Menguy, N., Brest, J., Baptiste, B., Tharaud, M., Ona-Nguema, G., Ikogou, M., Viollier, E., and Juillot, F. (2017) Nickel accelerates pyrite nucleation at ambient temperature. Geochemical Perspectives Letters, 5, 6-11.

Morse, J.W., and Arakaki, T. (1993) Adsorption and coprecipitation of divalent metals with mackinawite (FeS). Geochimica et Cosmochimica Acta, 57, 3635-3640.

Morse, J.W., and Luther III, G.W. (1999) Chemical influences on trace metal-sulfide interactions in anoxic sediments. Geochimica et Cosmochimica Acta, 63, 3373-3378.

Noël, V., Marchand, C., Juillot, F., Ona-Nguema, G., Viollier, E., Marakovic, G., Olivi, L., Delbes, L., Gelebart, F., and Morin, G. (2014) EXAFS analysis of iron cycling in mangrove sediments downstream a lateritized ultramafic watershed (Vavouto Bay, New Caledonia). Geochimica et Cosmochimica Acta, 136, 211-228.

Noël, V., Morin, G., Juillot, F., Marchand, C., Brest, J., Bargar, J.R., Muñoz, M., Marakovic, G., Ardo, S., and Brown Jr., G.E. (2015) Ni cycling in mangrove sediments from New Caledonia. Geochimica et Cosmochimica Acta, 169, 82-98.

O’Day, P.A., Rivera Jr., N., Root, R., and Carroll, S.A. (2004) X-ray absorption spectroscopic study of Fe reference compounds for the analysis of natural sediments. American Mineralogist, 89, 572-585.

Olson, L., Quinn, K.A., Siebecker, M.G., Luther, G.W., Hastings, D., and Morford, J.L. (2017) Trace metal diagenesis in sulfidic sediments: Insights from Chesapeake Bay. Chemical Geology, 452, 47-59.

Partin, C.A., Lalonde, S.V., Planavsky, N.J., Bekker, A., Rouxel, O.J., Lyons, T.W., and Konhauser, K.O. (2013) Uranium in iron formations and the rise of atmospheric oxygen. Chemical Geology, 362, 82-90.

Peiffer, S., Behrends, T., Hellige, K., Larese-Casanova, P., Wan, M., and Pollok, K. (2015) Pyrite formation and mineral transformation pathways upon sulfidation of ferric hydroxides depend on mineral type and sulfide concentration. Chemical Geology, 400, 44-55.

Rickard, D. (1995) Kinetics of FeS precipitation: Part 1. Competing reaction mechanisms. Geochimica et Cosmochimica Acta, 59, 4367-4379.

(1997) Kinetics of pyrite formation by the H2S oxidation of iron (II) monosulfide in aqueous solutions between 25 and $125 \mathrm{C}$ : the rate equation. Geochimica et Cosmochimica Acta, 61, 115-134.

Rickard, D., and Luther III, G.W. (2006) Metal sulfide complexes and clusters. Reviews in Mineralogy and Geochemistry, 61, 421-504.

(2007) Chemistry of iron sulfides. Chemical Reviews, 107, 514-562.

Rickard, D., and Morse, J.W. (2005) Acid volatile sulfide (AVS). Marine Chemistry, 97, 141-197.
Rickard, D.T. (1969) The chemistry of iron sulfide formation at low temperatures. Stockholm Contributions to Geology, 20, 67-95.

Rickard, D.T., and Luther III, G.W. (1997) Kinetics of pyrite formation by the H2S oxidation of iron(II) monosulfide in aqueous solutions between 25 and $125^{\circ} \mathrm{C}$ : The mechanism. Geochimica et Cosmochimica Acta, 61, 135-147.

Robbins, L.J., Lalonde, S.V., Saito, M.A., Planavsky, N.J., Mloszewska, A.M., Pecoits, E., Scott, C., Dupont, C.L., Kappler, A., and Konhauser, K.O. (2013) Authigenic iron oxide proxies for marine zinc over geological time and implications for marine eukaryotic metallome evolution. Geobiology, 11, 295-306.

Robbins, L.J., Lalonde, S. V., Planavsky, N.J., Partin, C.A., Reinhard, C.T., Kendall, B., Scott, C., Hardisty, D.S., Gill, B.C., Alessi, D.S., and others. (2016) Trace elements at the intersection of marine biological and geochemical evolution. Earth-Science Reviews, 163, 323-348.

Rouxel, O.J., Bekker, A., and Edwards, K.J. (2005) Iron Isotope Constraints on the Archean and Paleoproterozoic Ocean Redox State. Science, 307, 1088-1091.

Scholz, F., and Neumann, T. (2007) Trace element diagenesis in pyrite-rich sediments of the Achterwasser lagoon, SW Baltic Sea. Marine Chemistry, 107, 516-532.

Schoonen, M.A.A., and Barnes, H.L. (1991a) Reactions forming pyrite and marcasite from solution: I. Nucleation of FeS2 below $100^{\circ} \mathrm{C}$. Geochimica et Cosmochimica Acta, 55, 1495-1504.

(1991b) Reactions forming pyrite and marcasite from solution: II. Via FeS precursors below $100^{\circ} \mathrm{C}$. Geochimica et Cosmochimica Acta, 55, 1505-1514.

Scott, C., Lyons, T.W., Bekker, A., Shen, Y., Poulton, S.W., Chu, X., and Anbar, A.D. (2008) Tracing the stepwise oxygenation of the Proterozoic ocean. Nature, $452,456-459$.

Scott, C., Planavsky, N.J., Dupont, C.L., Kendall, B., Gill, B.C., Robbins, L.J., Husband, K.F., Arnold, G.L., Wing, B.A., Poulton, S.W., and others (2012) Bioavalability of zinc in marine systems through time. Nature Geoscience, 6, 125-128.

Shen, Y., Buick, R., and Canfield, D.E. (2001) Isotopic evidence for microbial sulphate reduction in the early Archaean era. Nature, 410, 77-81.

Swanner, E.D., Bekker, A., Pecoits, E., Konhauser, K.O., Cates, N.L., and Mojzsis, S.J. (2013) Geochemistry of pyrite from diamictites of the Boolgeeda Iron Formation, Western Australia with implications for the GOE and Paleoproterozoic ice ages. Chemical Geology, 362, 131-142.

Swanner, E.D., Planavsky, N.J., Lalonde, S.V., Robbins, L.J., Bekker, A., Rouxel, O.J., Saito, M.A., Kappler, A., Mojzsis, S.J., and Konhauser, K.O. (2014) Cobalt and marine redox evolution. Earth and Planetary Science Letters, 390, 253-263.

Sweeney, R.E. (1972) Pyritization during diagenesis of marine sediments. Department of Geology. University of California, Los Angeles.

Tardani, D., Reich, M., Deditius, A.P., Chryssoulis, S., Sánchez-Alfaro, P., Wrage, J., and Roberts, M.P. (2017) Copper-arsenic decoupling in an active geothermal system: A link between pyrite and fluid composition. Geochimica et Cosmochimica Acta, 204, 179-204.

Tostevin, R., Turchyn, A.V., Farquhar, J., Johnston, D.T., Eldridge, D.L., Bishop, J.K.B., and McIlvin, M. (2014) Multiple sulfur isotope constraints on the modern sulfur cycle. Earth and Planetary Science Letters, 396, 14-21.

Wan, M., Schröder, C., and Peiffer, S. (2017) Fe(III):S(-II) concentration ratio controls the pathway and the kinetics of pyrite formation during sulfidation of ferric hydroxides. Geochimica et Cosmochimica Acta, 217, 334-348.

Wang, Q., and Morse, J.W. (1996) Pyrite formation under conditions approximating those in anoxic sediments I. Pathway and morphology. Marine Chemistry, 52, 99-121.

Webb, S.M. (2005) SIXpack: a graphical user interface for XAS analysis using IFEFFIT. Physica Scripta, 2005, 1011.

(2011) The MicroAnalysis Toolkit: X-ray fluorescence image processing. AIP Conference Proceedings Vol. 1365, pp. 196-199.

Wilkin, R.T., and Barnes, H.L. (1996) Pyrite formation by reactions of iron monosulfides with dissolved inorganic and organic sulfur species. Geochimica et Cosmochimica Acta, 60, 4167-4179.

Wilkin, R.T., and Beak, D.G. (2017) Uptake of nickel by synthetic mackinawite. Chemical Geology, 462, 15-29.

Wolthers, M., Van der Gaast, S.J., and Rickard, D. (2003) The structure of disordered mackinawite. American Mineralogist, 88, 2007-2015.

Wolthers, M., Butler, I.B., and Rickard, D. (2007) Influence of arsenic on iron sulfide transformations. Chemical Geology, 236, 217-227.

Zeng, T., Arnold, W.A., and Toner, B.M. (2013) Microscale Characterization of Sulfur Speciation in Lake Sediments. Environmental Science \& Technology, 47, 1287-1296.

MANUSCRIPT RECEIVED OCTOBER 3, 2018

MANUSCRIPT ACCEPTED MARCH 18, 2019

MANUSCRIPT HANDLED BY DANIEL GREGORY

\section{Endnote:}

${ }^{1}$ Deposit item AM-19-76834, Supplemental Figures. Deposit items are free to all readers and found on the MSA website, via the specific issue's Table of Contents (go to http://www.minsocam.org/MSA/AmMin/TOC/2019/Jul2019_data/ Jul2019_data.html). 